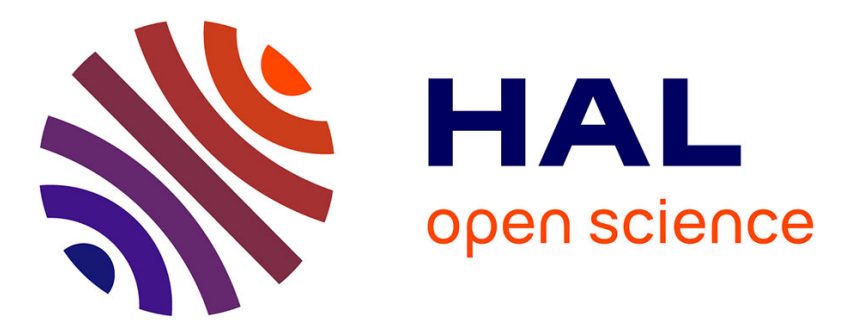

\title{
Use of radar rainfall estimates and forecasts to prevent flash flood in real time by using a road inundation warning system \\ Pierre Antoine Versini
}

\section{- To cite this version:}

Pierre Antoine Versini. Use of radar rainfall estimates and forecasts to prevent flash flood in real time by using a road inundation warning system. Journal of Hydrology, 2012, 416-417, pp.157-170. 10.1016/j.jhydrol.2011.11.048 . hal-00806300

\section{HAL Id: hal-00806300 \\ https://hal-enpc.archives-ouvertes.fr/hal-00806300}

Submitted on 13 May 2015

HAL is a multi-disciplinary open access archive for the deposit and dissemination of scientific research documents, whether they are published or not. The documents may come from teaching and research institutions in France or abroad, or from public or private research centers.
L'archive ouverte pluridisciplinaire HAL, est destinée au dépôt et à la diffusion de documents scientifiques de niveau recherche, publiés ou non, émanant des établissements d'enseignement et de recherche français ou étrangers, des laboratoires publics ou privés. 


\title{
Use of radar rainfall estimates and forecasts to prevent flash flood in real time by using a road inundation warning system
}

\author{
Versini, P.-A.
}

CRAHI-UPC, Barcelona, Spain

\begin{abstract}
Important damages occur in small headwater catchments when they are hit by severe storms with complex spatio-temporal structure, sometimes resulting in flash floods. As these catchments are mostly not covered by sensor networks, it is difficult to forecast these floods. This is particularly true for road submersions, representing major concerns for flood event managers. The use of Quantitative Precipitation Estimates and Forecasts (QPE/QPF) especially based on radar measurements could particularly be adequate to evaluate rainfall-induced risks. Although their characteristic time and space scales would make them suitable for flash flood modelling, the impact of their uncertainties remain uncertain and have to be evaluated.

The Gard region (France) has been chosen as case study. This area is frequently affected by severe flash floods, and an application devoted to the road network has also been recently developed for the North part of this region. This warning system combines distributed hydro-meteorological modelling and susceptibility analysis to provide warnings of road inundations. The warning system has been tested on the specific storm of the 29-30 September 2007. During this event, around $200 \mathrm{~mm}$ dropped on the South part of the Gard and many roads were submerged. Radar-based QPE and QPF have been used to forecast the exact location of road submersions and the results have been compared to the effective road submersions actually occurred during the event as listed by the emergency services.
\end{abstract}

Used on an area it has not been calibrated, the results confirm that the road submersion warning system represents a promising tool for anticipating and quantifying the consequences of storm events at ground. It rates the submersion risk with an acceptable level of accuracy and demonstrates also the quality of high spatial and temporal resolution radar rainfall data in real time, and the possibility to use them despite their uncertainties. However because of the quality of rainfall forecasts falls drastically with time, it is not often sufficient to provide valuable information for lead times exceeding one hour. 
53 Mediterranean regions are subject to violent flash floods, resulting in heavy economic damages, estimated at a billion Euros in France over the last two decades Gaume et al., 2004 and, in some cases, human casualties, as illustrated by the recent events in Nîmes (1988), Vaison-la-Romaine (1992), Tarragona (1994), Biescas (1996), Corbière (1999), Alger (2001), Gard (2002) and Var (2010). Flash floods are identified as the consequence of an intense rain event producing several hundreds of $\mathrm{mm}$ in few hours (Creutin and Borga, 2003; Collier, 2007; Younis et al., 2008). During this type of event, spatial and temporal variability of rainfall appears to be the main factor controlling the hydrological response (Chancibault et al., 2007; Le Lay and Saulnier, 2007) and this evolution is very difficult to predict. Flash floods typically occur in quick response watersheds for two main reasons: (i) a short concentration time due to the size generally under few hundreds $\mathrm{km}^{2}$, (ii) flood flows that are essentially composed of surface runoff water or at least fast responding runoff processes (Creutin, 2009). That makes very difficult for emergency management services to anticipate and deliver flash flood warnings in real time.

This is particularly true concerning the road network that could be strongly affected during flash floods. In a situation of risk, the state of the road network has appeared as a major concern within these affected regions for two main reasons. First, many flash flood victims are in fact motor vehicle passengers trapped in inundated roads (Staes et al., 1994; Bourque et al., 2007). Second, emergency services require a clear overview of possible road conditions in order to efficiently plan interventions and identify safe access or evacuation routes.

Based on these considerations, a Road Inundation Warning System (RIWS) for flash flood prone areas has been recently developed and tested on the North part of the Gard Region (France) frequently affected by flash floods (Versini et al., 2010a). Coupling a susceptibility analysis of river road intersections (representing one part of the vulnerability to flooding) based on geographical information (Versini et al., 2010b and

80 a) distributed hydrological model, the RIWS has provided promising results. Tested on 81 real cases, it was able to correctly assess the inundation risk with an acceptable level of 82 accuracy. Nevertheless, this previous work has opened many ways of investigation before being applied in a decision support system. First, operational services interested 
by the RIWS has advised to study its possible application on a territory where it has not been calibrated to test the transferability of the whole prototype. Secondly, as the spatiotemporal distribution of rainfall has appeared to have a major influence on the state of the road network, the hydrological model had to be adapted to take into account distributed rainfall products, especially those based on weather radar. Indeed, one important feature of road submersion is the significant number of targets (that could be located on very small watersheds) regarding the limited coverage of rain and stream gauges, making this framework close to ungauged conditions. For example, the Gard region $\left(580 \mathrm{~km}^{2}\right)$ is covered by 38 stream gauges for 2480 crossing structures.

Accurate quantitative precipitation estimates (QPE) are also crucial for operational flash flood forecasting. Ground-based operational weather radars currently appear as the only instrument able to provide valuable information with a high spatial $\left(1 \mathrm{~km}^{2}\right)$ and temporal (tens of minutes) resolution. The density of automated rain gauges network is generally too low and not adapted to flash flood short time and space resolutions. In this case rainfall estimation uncertainties are still a major factor limiting the accuracy of rainfall-runoff modelling (Moulin et al., 2009). Moreover, rainfall estimated using satellite remote sensing is still under development and not sufficiently advanced to be used in an operational mode. Consequently, radar QPE is accepted as one of the most reliable data that can be used for hydrological applications (Corral et al., 2000; Borga, 2006; Cole and Moore, 2008).

This is also the case concerning quantitative precipitation forecasts (QPF). Although few works have focused on using QPF based on weather radar data, results show significant improvements in the quality of forecasted hydrographs (Corral et al., 2000; Dolciné et al., 2001; Berenguer et al., 2005; Borga, 2006; Boudevillain et al., 2006; Van Horne et al., 2006; Vivoni et al., 2006; Cole and Moore, 2008). These radar-based QPF are usually limited to forecasting time ranging from 10 to 120 minutes. Tested on rather large basins (from hundreds to thousands $\mathrm{km}^{2}$ ), the anticipation of flow peak could be estimated, with enough quality, with a lead-time for up to few hours. It represents a notable improvement for fast response basins such those in Mediterranean regions. It is also recognized that the nature of the event has an important effect on the quality of the forecasted flow estimates. In Collier, 2007) a review is made to study how flash floods are forecasted considering the limitations and uncertainties involved in both meteorological and hydrological models of the forecasting system. The author 
117 concludes the possibility to deliver valuable information from a flash flood risk 118 management point of view limited to a lead-time of two hours.

119 This paper deals with a practical application of this statement. The main objective of the 120 present work is to test the use of radar-based QPE and QPF on a specific hydrological 121 application devoted to the road network. The spatio-temporal variability information 122 provided by the radar based precipitation estimates and forecasts will be tested using the 123 RIWS. The warning system will be firstly transported and adapted to a new basin

124 located in the South part of the Gard region. It will be then applied to reproduce the specific storm of 29-30 September 2007 during which 19 roads were submerged. Predicted road inundations will be compared to what actually occurred. This will allow us to assess both the transfer of the RIWS on an area where it has not been calibrated, and the use of the available QFE and QPF products for flood forecasting in a framework reproducing operational conditions.

130 This paper is organised as follows: the next section presents the scope of study in more 131 detail, including a description of the area of study, the rainfall products, and the RIWS.

132 Section 3 describes the methodology applied to: i) transfer and test the RIWS to the new 133 domain, and ii) test the information provided by the QPE/QPF, and their benefits in the 134 detection and prediction of inundated roads. The results obtained during the 29-30 135 September 2007 storm are presented in Section 4. Finally, Section 5 will conclude on 136 both topics presented in Section 3.

\section{2- Presentation of the case study}

\section{2-1 The Gard region}

142 The Gard region (South of France) was used to develop and test the RIWS because it is 143 frequently affected by severe flash floods (Delrieu et al., 2005; Gaume et al., 2009).

144 This region has a typical Mediterranean climate characterized by frequent and very 145 heavy storm events occurring especially in autumn. The 1 in 10 year daily precipitation 146 exceeds $100 \mathrm{~mm}$ on the plateaus (eastern part) and $150 \mathrm{~mm}$ in the mountainous western 147 part of the area (CNRS/INPG, 1997). Single storm events can produce locally hundreds 148 of millimetres within few hours.

149 During these storms, roads are often flooded. Significant inundation occurs at least once 150 a year on average on the same vulnerable section of the road network. $40 \%$ of the 
151 victims of floods in the Gard during the last 50 years were motorists Antoine et al., 152 2001. During the extreme September 2002 flood (Delrieu et al., 2005; Ruin et al., 153 2008), about 200 emergency vehicles were seriously damaged or destroyed by the

154 flows. For these reasons, the monitoring of the road network during flash flood events 155 has become a major concern for management services. The inundated road sections are 156 now systematically inventoried during or after every major event by the local services in 157 charge of road maintenance. It is based on these considerations that the first attempt 158 represented by the RIWS has been conducted to forecast the possible inundated road 159 (Versini et al., 2010a). A summary of this prototype will be described further (Section $1602.3)$.

161 This study mainly focuses on the southern part of the Gard region (Fig. 1) where both 162 Vidourle and Vistre watersheds join the scrubland of La Camargue (swamp zone of the 163 Rhône Delta) before entering into the Mediterranean Sea. Both watersheds are located 164 outside the calibration area of the RIWS and differ from this one from a geographical 165 point of view. The Vidourle basin has a drainage area of $833 \mathrm{~km}^{2}$ and an altitude 166 ranking from $3 \mathrm{~m}$ to $770 \mathrm{~m}$. This watershed is essentiality covered by rural landscapes: 167 vines and forest. The Vistre watershed $\left(476 \mathrm{~km}^{2}\right)$ is quite different with lower altitudes 168 (4 $\mathrm{m}$ to $200 \mathrm{~m}$ with an average altitude of $70 \mathrm{~m}$ ) and a more urbanized land with the 169 presence of the city of Nîmes (150.000 inhabitants) upstream of the basin. Because of 170 this very flat topography, river floodplains are wider and easily inundated.

172 2-2 Meteorological and Hydrological data:

173 Known as an area very sensitive to flash flood, the Gard region is covered by a dense 174 network of rain gauges and two weather radars (Nîmes and Bollène). Rain gauge and 175 discharge data used in this study were collected and analysed in the framework of the 176 Cevennes-Vivarais hydro-meteorological observatory (OHM-CV, 177 www.lthe.hmg.inpg.fr/OHM-CV). This observatory is a research initiative aiming at 178 monitoring and understanding intense Mediterranean storms and flash floods (Delrieu, 179 2004). On the other hand, two different services are in charge of hydro-meteorological 180 warning and are authorized to deliver QPE and QPF for flood management in real-time: 181 (i) the service of flood prevention (SPC for "Service de Prévention des crues" in 182 French) is the local service in charge of flooding prevention specially devoted to the 
183 Gard region, and (ii) the national meteorological agency, Meteo France (MF hereafter), 184 that delivers radar-based rainfall maps for the whole country. Processing of this 185 different data is briefly described below.

\subsubsection{Cevennes-Vivarais hydro-meteorological observatory data}

187 Seventeen automatic hourly rain gauges are located within or close to the Vidourle and 188 Vistre watersheds. They have been set up for flood forecasting purposes. While the 189 density of about two gauges per $100 \mathrm{~km}^{2}$ is quite good, it could not enable accurate 190 estimations of rainfall intensities by spatial interpolation at time and space scales suited 191 to flash flood dynamics: sub-hourly time step and kilometric scale (Moulin et al., 2009).

192 OHM-CV uses an ordinary kriging technique (Journel and Huijbregts, 1978), using a spherical variogram model, to interpolate the rain gauge measurements and map rainfall rates at a 15-minutes time step and $1 \mathrm{~km}^{2}$ grid covering the area of study Lebel et al., 1987. As rain gauge data are only available at hourly time step, constant rainfall intensities were assumed for the entire hours.

197 The Vidourle catchment is well instrumented with numerous hourly stream gauges.

198 Three dams (Ceyrac, Conqueyrac, and La Rouvière) are located in the upstream part 199 and four gauge stations (Quissac, Vic-Le-Fesq, Sommières, Marsillargues) on the principal stream in the Vidourle valley (see Figure 1). On the other hand, the Vistre catchment is poorly instrumented with only one station located at the watershed outlet (Le Cailar).

\subsubsection{Gard region data}

205 Complex SPC inundation forecasting system Bressand, 2002 is able to deliver valuable spatial rainfall intensity at the $1 \mathrm{~km}^{2}$ scale every 5 minutes. Although this system has been created by the private company REAH®, some basic elements can be explained on the processes involved to correct and generate radar images Ayral, 2005. The Gard region is divided into 5 windows corresponding approximately to the five main basins

210 of the region (Vistre, Vidourle, upstream Hérault, Gardon and upstream Cèze, Gardon 211 and downstream Cèze). In each window, the radar maps are specifically adjusted with 212 the rain gauge measurements using a calibration factor (FC). This coefficient is

213 calculated every 5 minutes using the three last measurements (Eq. 1). It usually varies between 0.5 and 3 . 


$$
F C=\frac{\sum_{i=1}^{n} P_{i}}{\sum_{i=1}^{n} R_{i}}
$$

216 Where $P_{i}$ is the rain gauge measurement, $R_{i}$ is the radar measurement at the rain gauge

217 location, $n$ is the total number of rain gauges used to adjust radar data.

218 Precipitation forecasts are also calculated for different lead times varying between 5 219 minutes to one hour. In this case, FC used to adjust radar-based rainfall is fixed. This

220 represents one of the weaknesses of the system. Consider the radar/rain gauge relation is 221 constant during the storm can lead to misestimate -often underestimate- rainfall 222 forecast.

\subsubsection{Meteo France data}

225 Meteo France produces QPE and QPF every 5 minutes over the whole country at the 1 $\mathrm{km}^{2}$ scale based on an aggregation of radar data. After a processing chain that corrects ground clutter, partial beam blocking, VPR effects, and advection, the radar image is corrected using the rain gauges data (Tabary, 2007; Tabary et al., 2007). The principle to fit radar data to rain gauge values is also based on the use of a calibration factor. Two differences with the FC calculated for SPC data can be noted. First, this one takes into account previous rain gauge and radar measurements over a longer period. In order to give more importance to the newest values, they are multiplied by weights increasing with time. Second, a "memory" coefficient is added to constrain FC to converge to a monthly calibration factor $\mathrm{FC}_{\text {month }}$ when there is little rain between two events.

$$
\mathrm{FC}=\frac{\sum_{\mathrm{i}=\mathrm{H}-\mathrm{M}}^{\mathrm{H}} \omega_{\mathrm{i}} \cdot \mathrm{P}_{\mathrm{i}}+\mathrm{C}_{\text {rec }}}{\sum_{\mathrm{i}=\mathrm{H}-\mathrm{M}}^{\mathrm{H}} \omega_{\mathrm{i}} \cdot \mathrm{R}_{\mathrm{i}}+\frac{\mathrm{C}_{\text {rec }}}{\mathrm{FC}}}
$$

236 Where $M$ is the period on which the factor is calculated, $H$ is the lead time, $P_{i}$ is the rain 237 gauge measurement at time $H, R_{i}$ is the radar measurement at the rain gauge location at 238 time $H, \omega_{i}$ is the weight to filter oldest values at time $H, C_{r e c}$ is the memory coefficient, $239 F C_{\text {month }}$ is the monthly coefficient. 
240 QPF are produced for different lead times ranging from 5 to 70 minutes. The method used (Juvanon du Vachat et al., 1995a; Juvanon du Vachat et al., 1995b) derives the motion field between consecutive radar scans from the distance of the mass centers of two corresponding radar echoes. The centers are assumed to be representative for

244 individual convective cells. This motion field is then extrapolated and applied to 245 produce future rainfall field.

\section{2-3 The Road Inundation Warning System}

248 The RIWS for flash flood prone area has been developed within the FLOODsite ${ }^{1}$ project 249 funded by the European Sixth Framework Program. It focuses on intersections between 250 road and river networks that can be flooded during a flash flood event, and it has been 251 calibrated and tested on the North part of the Gard region (called "calibration area" in 252 the rest of the paper). Both components of the RIWS (susceptibility analysis and 253 hydrological model) are briefly presented below. For a detailed presentation, please 254 refer to Versini et al., 2010a; Versini et al., 2010b).

\subsubsection{Susceptibility rating method}

256 An inventory of past road inundations was carried out by the public agency in charge of 257 the road management on the North part of the Gard region, outside the studied area 258 (Lignon, 2004). As comprehensive as possible, its objective was to collect the location 259 of the most frequent road submersions. Based on the employees' experience and 260 memory, it contains the exact location of 167 road sections flooded (and noted) during 261 the last 40 years on the main road network. From this inventory, four categories of 262 susceptibility to flooding (high, medium, low, and safe) were defined. Geographical 263 characteristics (local altitude and slope, upstream watershed area) of crossing structure 264 have been highlighted to explain this susceptibility to flooding and allocate every road 265 intersection in a category. Using historical road inundations and their estimated 266 frequency of flooding, a statistical distribution of return period of flooding was 267 calculated for each susceptibility category.

\subsubsection{Hydrological model}

270 The CINECAR hydrological model (Gaume et al., 2004) has been selected to simulate 271 distributed discharges. Developed specifically to model flash floods, it represents the

\footnotetext{
${ }^{1}$ http://www.floodsite.net/
} 
272 entire watershed as a network of river reaches having a simple rectangular cross-section, 273 connected to two rectangular slopes (characterized by areas of few $\mathrm{km}^{2}$ ). The US Soil 274 Conservation Service (SCS) Curve Number (CN) model is used to calculate the 275 evolution of the runoff coefficient on each slope during the storm event, and the 276 kinematic wave model is used to route the flows on the slopes and through the network 277 of river reaches. The CINECAR model has been calibrated and validated based on the 278 discharge time series available on 12 watersheds over the period 2000-2005. Because of 279 the lack of available radar data, OHM-CV kriged data was used for these procedures.

280 The performance of the model was evaluated on several rainfall events with a total 281 rainfall exceeding $100 \mathrm{~mm}$ available on this period. Acceptable results were obtained 282 (average Nash criterion value of 0.3) that looked comparable to those obtained in 283 similar studies (Borga, 2008). Based on this study, it has been considered the 284 CINECAR model depends on only two parameters: widths of the rectangular sections 285 representing the rivers that can be fixed a priori and adjusted during the storm depending on the flood magnitude, and the $\mathrm{CN}$ that can be also determined a priori from an expert judgment.

\subsubsection{Risk levels}

290 Finally, every road intersection is characterized by a susceptibility category and is connected to a river reach where the discharge is simulated. These discharges are compared at each time step with the theoretical return period thresholds for two, ten, and fifty years: $\mathrm{Q}_{2}, \mathrm{Q}_{10}$ and $\mathrm{Q}_{50}$. These theoretical return periods are approximated using a regional discharge quantile estimation method, the Crupedix method Cemagref, 1980, adjusted for France. Inundation risk levels are defined based on the susceptibility category and the discharge magnitude, or only on the discharge magnitude if susceptibility analysis is not used (see Table 1). Three levels of risk are assigned: high submersion risk (HSR), significant risk (SR), and moderate risk (MR). A warning is issued when one of the thresholds is exceeded.

\section{3- Application of the RIWS and protocol assessment}

302 3-1 The case of the 29-30 September 2007

303 The rainfall event happened during the night between the 29 and 30 September 2007 and was one of the most important that occurred in the Vistre and Vidourle watersheds 
over the last years. A stationary storm with a "V" shape moved from the west to the east and intensive precipitations fell on the central part of the watersheds between 22:00 and 00:00. Between 80 and $120 \mathrm{~mm}$ were measured on both watersheds and locally more than $200 \mathrm{~mm}$. At 2:30 the Vidourle river overflowed in Sommières. Rainfall forecasts preventing this event and issued by the French meteorological agency Meteo France were quite accurate. At the beginning of the storm (20:00), they issued a moderate warning reporting "heavy rainfall storm" during the night. An average rainfall of $50 \mathrm{~mm}$ was forecasted on the region around Nîmes and locally more than $150 \mathrm{~mm}$. Road management and rescue services were advised of possible troubles during the night.

314 Finally, important damages occurred during this event. Some houses and garages were 315 submerged, and the road network was particularly affected. Nineteen roads were closed 316 during the night by the regional services and reopened one after the other the next day. 317 It made rescue operations difficult and has represented a major threat to lives. The fire 318 brigade and the regional service of rescue recognized about fifty interventions due to the inundations. Despite the advice he has been given, a motorist crossed the Vidourle and was swept away by the important flow.

\section{3-2 Methodology}

323 The objective is to assess the use of the quantitative precipitation estimates and 324 forecasts by the RIWS. First, a direct analysis of the QPE/QPF will be conducted to evaluate the quality of the RIWS input. Then, the RIWS has to be transferred and applied on the South part of the Gard region where it has not been calibrated. That means both susceptibility analysis and hydrological model will be assessed on a new landscape with another road network configuration. Their results will be compared to those obtained on the calibration area. Finally, RIWS will be applied on the 29-30 September 2007 storm and its results will be analysed comparing the warnings it delivers to the actually inundated roads. The three steps, direct QPE/QPF analysis, the RIWS transfer and the RIWS assessments with QPE and QPF are described thereafter.

\subsubsection{Direct analysis of precipitation}

335 Both QPE and QPF produced by both services (MF and SPC) will be compared and evaluated. Particular attention will be given to the spatio-temporal variability of the rainfall distribution. Both hyetograms and rainfall accumulation maps will be analysed 
338 at the watershed scale for the Vistre and the Vidourle basins. These data will be compared to kriging interpolation-based, used as reference. It is assumed that kriged

340 data correctly represent the temporal variability of the precipitation at such large spatial and temporal scale. The local heterogeneities of rainfall that are not captured by the rain gauge network should have a relative low impact on the mean estimated rainfall. Moreover, kriged data were processed after the storms and do not include any errors associated with real time data (as QPE and QPF can do). In order to study the different QPE at a smaller scale more representative of small ungauged watersheds, comparison between radar-based kriged data and QPE accumulations will be also drawn at the cell scale $\left(1 \mathrm{~km}^{2}\right)$.

\subsubsection{Road Inundation Warning System transfer}

350 First, the susceptibility rating method is applied. Based on geographical information 351 (local slope and altitude, watershed area), the river road intersections of the Vistre and 352 Vidourle watersheds will be spread in the four categories of susceptibility (high, 353 medium, low and safe). The verification will consist in analysing the susceptibility category of the road sections effectively submerged during the 29-30 September 2007 storm. Locally, where intersections are subjected to the same rainfall hazard, the most susceptible intersections should be flooded in priority. As the susceptibility rating method has been calibrated on a region quiet different from the studied watersheds, its extrapolation could be inappropriate without any adjustments.

359 The transfer of the hydrological model has also to be assessed. Once the watersheds

360 have been desegregated as a network of river reaches connected to sub-basins, the parameters have to be evaluated a priori. The widths of the river reaches have been

362 fixed to those representing a moderate discharge at the beginning of the event, and can be modified during the storm according to the discharge magnitude. The key parameter is the $\mathrm{CN}$ because it represents the evolution of the runoff coefficient value during the storm taking into account the initial condition. Based on the work realized in Versini et al., 2010a), an a priori range of $\mathrm{CN}$ will be used. The simulated discharges will be compared to the observations available for the stream gauges of the Vistre and Vidourle watersheds. In order to test the viability of this calibration a priori, simulated discharges at the gauge stations will be also calculated using a value especially calibrated for this 
event (CNcal). The simulation achieved with $\mathrm{CNcal}$ will represent the best performance we can expect from the hydrological model at the gauged basin scale. Every simulation will be evaluated using the Nash efficiency (Nash, 1969):

$$
\text { Nash }=1-\frac{\sum_{\mathrm{i}=1}^{\mathrm{n}}\left(\operatorname{Qobs}_{\mathrm{i}}-\mathrm{Qsim}_{\mathrm{i}}\right)^{2}}{\sum_{\mathrm{i}=1}^{\mathrm{n}}\left(\operatorname{Qobs}_{\mathrm{i}}-\overline{\mathrm{Qobs}}\right)^{2}}
$$

Where $Q \operatorname{sim}_{i}$ represent the simulated discharges, $Q o b s_{i}$ the observed discharges, $\overline{Q o b s}$ the average observed discharge during the storm, and $n$ the number of time steps.

\subsubsection{RIWS assessment using radar-based QPE and $Q P F$}

The skill of the RIWS is assessed using a classical contingency statistical analysis. An efficient RIWS should be able to identify a large proportion of the actually observed inundations and limit the number of "false alarms" - predicted inundations that are not observed. Four criteria are therefore used to assess the performance of the proposed RIWS using the available information on the actually observed inundations:

- Probability of Detection (POD) calculated as the ratio between the number of inundated sections where a warning has been issued (Correct Warnings) and the total number of inundated road sections:

$$
\mathrm{POD}=\frac{\# \text { Correct Warnings }}{\# \text { Inundated roads }}
$$

- False alarm ratio (FAR) calculated as the ratio between the number of noninundated sections where a warning has been issued (false warnings) and the total number of warnings delivered by the RIWS:

$$
\mathrm{FAR}=\frac{\# \text { False alarms }}{\# \text { Warnings }}
$$

- Correct negative (COR) represents the ratio between the number of noninundated sections where a no warning has been issued (Safe) and the total number of misses: 


$$
\mathrm{COR}=\frac{\# \text { Safe }}{\# \text { Safe }+\# \text { Misses }}
$$

395 These very intuitive skill scores are computed using rainfall estimates for both services 396 in a framework reproducing operational conditions. Four lead times (15, 30, 45, and 60 397 minutes) are used to test the accuracy of this data and its possible degradation over time.

398 In addition, the false positive rate (FPR), which is the ratio between false alarms and the 399 number of effective non-inundated road sections (Non inundated roads), is computed.

400 Coupled with the maximum value of POD over the event, it is used to plot ROC 401 (Receiver Operating Characteristic) curves and evaluate the sensibility of the two-class 402 prediction problem (flooded - not flooded). It will be particularly useful to compare the 403 results with those obtained on the calibration area, using or not the susceptibility 404 analysis:

$$
\mathrm{FPR}=\frac{\# \text { False alarms }}{\# \text { Non inundated roads }}
$$

406

407

408

409

410

411

412

413

414

415

416

417

\section{4- Results}

4-1 Radar-based QPE and QPF direct analysis

Rainfall accumulations during the entire storm have been computed in a window including both Vistre and Vidourle watersheds for every type of data (OHM-CV kriging, QPE and QPF from MF and SPC). They are presented in Figure 2. Scatter plots comparing radar-based QPE with kriged data are illustrated on Figure 3. Hyetograms representing mean areal intensity (with 15 minutes time step) at the watershed scale for both Vidourle and Vistre watersheds are also presented for every rainfall data in Figure 4.

\subsubsection{Quantitative Precipitation Estimates}

First, the spatial distribution of rainfall is studied. Despite the location of the storm core is the same for the three estimations, a marked difference in rainfall amount can be noted. The maximum accumulation exceeds $250 \mathrm{~mm}$ for the SPC estimates whereas it only exceeds $150 \mathrm{~mm}$ for MF data, respectively $200 \mathrm{~mm}$ for the kriging. This is also corroborated by Vic-Le-Fesq rain gauge data located where the most intense 
precipitation occurred. A total amount of $175 \mathrm{~mm}$ was locally measured whereas 215

$425 \mathrm{~mm}$ were estimated by SPC QPE, respectively $130 \mathrm{~mm}$ for MF QPE. It is also confirmed by scatter plots on Figure 3. At the $1 \mathrm{~km}^{2}$ scale, MF QPE have a tendency to underestimate the most intense precipitation. On the other hand, SPC QPE overestimate some of the highest accumulations measured on the Vidourle watershed, but the highest differences with kriging are located on the cells where the precipitation in interpolated. The numerous underestimations for the lowest values correspond to the Vistre watershed. As it has been shown above, SPC data is calibrated for two different geographical windows on the Vidourle and Vistre watersheds. This is strongly visible on the accumulation map with local intensities higher than $250 \mathrm{~mm}$ measured on the

434 Vidourle window neighbouring a value three times lesser on the Vistre window. A short band is shared by both windows where both estimated rainfall can be compared. A significant difference around $35 \%$ is noted. It can be assumed that the FCs used during the storm tend to overestimate rainfall on the Vidourle window and/or to underestimate on the Vistre one.

439 Second, temporal distribution of rainfall is analysed on both watersheds. Looking at the hyetograms (Fig. 4), precipitation estimates appear to be very different from a data to another on the Vidourle basin. For example, at 22:00 the kriging interpolation-based displays a maximum intensity of $15 \mathrm{~mm} / \mathrm{h}$. It is well reproduced by the SPC estimates

$443(17 \mathrm{~mm} / \mathrm{h})$, but widely underestimated by MF ones $(10 \mathrm{~mm} / \mathrm{h})$. On the other hand, the

444 Vistre case shows a coherent rain amount between both services and the kriged data.

445 The maximum intensity of $38 \mathrm{~mm} / \mathrm{h}$ arises between 23:00 and 00:00 on the three 446 observed hyetograms. The large overestimation highlighted on SPC rainfall accumulation map is only slightly reflected on both hyetograms because the highest precipitations fell outside the studied watersheds.

\subsubsection{Quantitative Precipitation Forecasts}

452 QPF provided by MF and SPC are very heterogeneous depending on the studied 453 watershed, but they all have a strong tendency to underestimate the storm intensity for 454 the largest lead times. On the Vistre watershed, where rainfall was the highest, SPC 455 forecasts can lose up to $30 \%$ of the maximum intensity while MF more than $60 \%$ (see Fig. 4). This time, SPC QPF show a coherent merging between both zones because the 
same FC equal to 1 is used (Fig. 2). Nevertheless, despite the storm stationarity is well represented, they have a tendency to underestimate precipitation with time, especially for the highest intensities. It should be interesting to obtain additional information on the SPC QPF production to interpret them more thoroughly.

MF QPF appear to be more uncertain. Accumulation maps (Fig. 2) show a tendency to transfer the convective system to the east part of the Vistre watershed. This situation corresponds to the typical case of a regenerative system over several hours, whom the system velocity is different from the cells velocities composing the system. During a certain time, the system velocity is almost equal to zero and the storm is nearly stationary while the cells -with a lifetime shorter- are moving eastward. The method used to extrapolate motion field in operational mode capture the movement of small scale structures, typically the scale of the convective cells. In most cases this diagnosis is appropriate. Here, the displacement obtained suggests a movement towards the east, which evacuates the system too quickly and does not restore the stationarity of the regenerative system. As the forecasted system is moved to the east, it always crosses the Vistre watershed and few affect the predictions on this basin. A slight overestimation is noted for the 30 minutes forecast. Conversely, the forecasts on the Vidourle watershed are highly affected by this error. The precipitation peak that occurred at 22:00 is strongly underestimated and almost absent in the one hour forecast.

\section{4-2 Road Inundation Warning System transfer}

\section{4-2-1 Susceptibility analysis}

479 The road susceptibility rating method has been applied on both Vidourle and Vistre 480 watersheds. 468 river road intersections were identified using existing river and road 481 network GIS layers. These road intersections have been classified into the 4 categories defined above. The high susceptible category contains $12 \%$ of the river crossings; respectively $20 \%, 50 \%$ and $18 \%$ for the medium, low and safe categories. Susceptibility repartition of Vistre and Vidourle intersections is very similar to those obtained on the North part of the Gard where the method was calibrated (see Table 2). Although the density of linear road is quite the same $\left(1511 \mathrm{~km} / \mathrm{km}^{2}\right.$ in the calibration area vs $1433 \mathrm{~km} / \mathrm{km}^{2}$ on the study area), the density of river intersections is different: 0.87 intersections $/ \mathrm{km}^{2}$ vs 0.44 intersections $/ \mathrm{km}^{2}$. The river network is less dense on the South part of the region and the number of intersections with the road network is also lower. 
490 This is due to the geographical characteristics of the region: flatter and more urbanised and domesticated.

492 Concerning the twenty-three river road intersections responsible for the 19 flooded 493 roads during the 29-30 September 2007 storm, five of them are located upstream very 494 small watersheds $\left(<1 \mathrm{~km}^{2}\right)$, and seven are located upstream small watersheds $\left(<10 \mathrm{~km}^{2}\right)$. 495 For these watersheds, the concentration time is very short, lesser than 15 minutes for the 496 smallest ones, making difficult interventions between rainfall and its possible 497 consequences. Among the 468 river crossings identified in the study area, the twenty498 three inundated crossing structures are characterized by rather high levels of susceptibility (see Table 2). Eight of them (35\%) are included in the high susceptibility category and seven (30\%) in the medium one. Seven $(30 \%)$ are in the low category and one $(5 \%)$ in the safe category. As they are characterized by a distribution of level of susceptibility focused on the highest values, submerged crossing structures seem to be related with the susceptibility categories defined in the calibration area (yet geographically and topographically different). Considering this only event and the small size of classes, it is not possible to be more conclusive.

\section{4-2-2 Hydrological model}

507 Out of the eight stream gauges located on both Vistre and Vidourle watersheds, only four have registered a peak of discharge during the studied storm. All gauges of the upstream part of the Vidourle catchment did not receive sufficient water to measure such an increase. This is particularly true for the three dams for which the output discharge remained constant during the entire storm. Finally, discharge peaks were registered only at Vic-Le-Fesq $\left(505 \mathrm{~km}^{2}\right)$, Sommières $\left(620 \mathrm{~km}^{2}\right)$, Marsillargues $(798$

$\left.513 \mathrm{~km}^{2}\right)$ and Le Cailar $\left(440 \mathrm{~km}^{2}\right)$; respectively $25.8 \mathrm{~m}^{3} / \mathrm{s}\left(0.051 \mathrm{~m}^{3} / \mathrm{s} / \mathrm{km}^{2}\right), 232.5 \mathrm{~m}^{3} / \mathrm{s}$ $514\left(0.375 \mathrm{~m}^{3} / \mathrm{s} / \mathrm{km}^{2}\right), 235.0 \mathrm{~m}^{3} / \mathrm{s}\left(0.294 \mathrm{~m}^{3} / \mathrm{s} / \mathrm{km}^{2}\right)$, and $58 \mathrm{~m}^{3} / \mathrm{s}\left(0.132 \mathrm{~m}^{3} / \mathrm{s} / \mathrm{km}^{2}\right)$. As the 515 discharge peak measured at Vic-Le-Fesq is very low -a specific discharge bellow 0.1 is 516 hardly represented by the hydrological model- only the three remaining gauges have 517 been kept to assess the model simulations.

518 First, these observations have been compared to the discharges obtained by the CNs 519 selected a priori and used in an operational mode. In the calibration process, Versini et 520 al., 2010a) have proposed a range of two $\mathrm{CN}$ values related to the date and the antecedent rainfall amount. The beginning of the autumn season combining with a total 
522 amount of antecedent precipitation lesser than $100 \mathrm{~mm}$ carries to use both 40 and $50 \mathrm{CN}$

523 values. Second, a calibrated $\mathrm{CN}$ (CNcal) has been estimated in a dichotomous way, 524 calibrating a first $\mathrm{CN}$ for all the sub-basins located upstream Sommières, a second $\mathrm{CN}$ 525 for the sub-basins between Sommières and Marsillargues, and a third one for the Vistre 526 sub-basins. The objective of this calibration is to assess the hydrological model's ability 527 to reproduce correctly the studied storm and to have an idea on the spatial distribution 528 of the CN. These simulations have been carried out using OHM-CV kriged data, and 529 both SPC and MF estimates. The different hydrographs and the Nash efficiencies 530 evaluating the simulation performance are presented in Figure 5 and Table 3.

531 The simulations obtained with the CNs selected a priori appear to be acceptable and similar to those obtained on the calibration area (see Versini et al., 2010a). They are particularly reliable on Sommières watershed where the peak of the hydrograph is well represented (Figure 5-a). As for Le Cailar basin, discharges calculated with $\mathrm{CNcal}$ are almost all enclosed between both discharges calculated with the a priori CNs, suggesting the hydrological model is well calibrated on these parts of the study area. Note that the shape of Le Cailar hydrograph is not well reproduced due to the complex structure of the basin through highly urbanized and irrigated. Conversely, at Marsillargues (Figure 5-b), the CNcal values are systematically outside the range defined by both a priori $\mathrm{CNs}$. The $\mathrm{CN}=50$ tends to underestimate the discharge for the MF estimates whereas the $\mathrm{CN}=40$ tends to overestimate the discharge using SPC data.

542 Simulated discharges obtained with the calibrated values show the simulations could 543 seriously be improved.

544 It is clear the results depend on the type of precipitation data used. The previously presented differences in rainfall estimates represent a factor explaining the results of 546 hydrological modelling simulations. The calibrated CNcal corrects the difference 547 between both radar-based QPE (MF and SPC) and illustrates QPE are far from perfect. 548 An underestimation of rainfall is offset by a larger $\mathrm{CN}$, and reciprocally. Although 549 rainfall amount based on kriging seems to be well represented at the watershed scale 550 (Fig. 4), the corresponding simulations appear to be the worst (lowest Nash efficiency). 551 In these cases, the simulated hydrographs are late in comparison with the observed ones, and this problem of synchronization drastically affects the Nash efficiency computation

553 (Table 3). This can be explained by the low spatio-temporal resolution of this data, but 554 also by the rainfall-runoff model structure and calibration. The river widths that conduct 
555 the transfer have been fixed and may be not adequate in this case. SPC and MF 556 estimates delivered in real time seem to better simulate the discharge. Once the bias is 557 corrected (compensated by the value of $\mathrm{CN}$ ), the radar leads to a well representation of 558 the flood dynamics.

559 Further conclusions cannot be issued about the quality of the different QPEs because of

560 the simplicity of the hydrological model. As CINECAR only represents surface runoff, 561 it does not take into account sub-surface processes for instance. This component can be 562 significant for large basin as illustrated by the shape of the observed hydrographs. Its 563 simplification may overestimate direct runoff; that will conduct to overestimate 564 discharge on small basins where this process is prominent.

565 Nevertheless, the objective of this calibration procedure was to assess the hydrological 566 model's ability to reproduce the observed discharge and to define optimised $\mathrm{CN}$ for 567 each QPE. These CNcal values will be applied on the sub-basins located upstream the 568 stream gauges. They represent the best performance we can expect from the model at 569 the gauged basin scale. On the other sub-basins of the studied area (downstream 570 Marsillargues and Le Cailar basins), where no stream gauge is located, CNcal has been 571 extrapolated from the values previously calibrated on the Vistre watershed. CNcal calculated with the Le Cailar stream gauge have been implemented on these sub-basins for two reasons: (i) proximity because almost all these sub-basins are located in the

574 Vistre watershed, (ii) geographical similarity because they are characterized by the same $575 \mathrm{CN}$ value estimated by the USDA method (USDA, 1985) using land occupation and soil 576 infiltration capacities, It is finally assumed the hydrological model with its restrictions can be applied on the entire study area.

\section{4-3 RIWS assessment using radar-based QPE and QPF}

583 The RIWS has been applied in a framework reproducing operational conditions during 584 the night of the 29 and 30 September 2007. For each time step $t_{i}$, warnings have been 585 computed using radar estimates available on real time (for both SPC and MF services) 586 from the beginning of the storm until time step $t_{i}$, but also kriged data. To prevent from the floodings that can occur in the near future, rainfall forecasts associated with both 
radar-based QPE have been used for the four following lead times: 15, 30, 45, and 60 minutes. To assess the pertinence of using radar-based QPE and QPF, the RIWS has been employed by testing different options: i) the susceptibility analysis has been turned on and off, ii) the hydrological model has been used with a priori values of $\mathrm{CN}=40$ and

$592 \mathrm{CN}=50$, and also with the calibrated values (CNcal) defined in Section 4.2.2. The results

593 have been evaluated using the different skill scores and compared with those obtained in

594 the calibration area. They are summarized in Table 4 and the most significant are 595 represented on Figures 6.

\section{4.3.1 On the use of radar-based QPE}

597 The results obtained with kriged data are very often worse than those obtained with radar-based QPE (see Table 4). Almost no inundated roads (POD=14\%) are detected by the RIWS with $\mathrm{CN}$ equal to 40. The use of the calibrated CNcal can get the best discharge simulations at the location of the stream gauge, but fails in reproducing the exceedance warning thresholds, especially for the intersections not located on a major stream (where most of the inundations occurred). Moreover, COR scores are always worse than those computed with radar-based QPE. Looking at the results in details, these bad scores are due to a higher number of misses and a lower number of correct warnings. The number of false alarms -similar to that obtained for radar-based QPE indicates that an underestimation of the precipitation is not solely responsible for the non-detection of the inundations; otherwise, the total number of false alarms should be lower. At small scale, the kriging-based interpolation of rain gauge measurements is not able to represent the spatio-temporal variability of rainfall, which is essential in this study. Moreover, it can be seen that the evolution of the different skill scores suffers a

611 delay of at least one hour compared to those computed from the others QPE (see Figure

612 6). This is due to the under-estimation of the first rainfall peaks (see Figure 4), and the 613 uniform distribution of the hourly data on the four 15 minutes time steps because the 614 most intense rainfall occurred at the beginning of an hour (18:00).

615 Using SPC QPE, around 80\% of the flooded roads are detected with the CNcal - for 616 which the simulated discharges were the best - (see Figure 6). The scores obtained for $617 \mathrm{CN}=50$ are very similar to those calculated with $\mathrm{CNcal}$ and decrease when $\mathrm{CN}=40$ is 618 used (POD drops to 60\%). As most of the floodings were located downstream the 619 gauged basins, the detection is clearly influenced by the choice made to extrapolate the 
$620 \mathrm{CN}$ values. The use of the $\mathrm{CN}$ adjusted on Le Cailar basin (the high value of 46) leads

621 to simulate significant discharges, high enough to exceed the warning thresholds.

622 In this best case, the remaining 20\% missed floodings are located on the Vistre 623 watershed. This should not be related to a possible under-estimated precipitation on the 624 Vistre window because the RIWS applied with MF or kriged data is also not able to 625 detect these floodings (Figure 6). As the hydrological model seems to be able to 626 reproduce correctly observed discharge at the Vistre gauge station, it has to be assumed 627 that the use of an average $C N$, distributed on the entire Vistre watershed, is not adapted. 628 The model should be influenced by the heterogeneous precipitation distribution on this watershed whose downstream part was particularly affected by the most intense rainfall.

630 A better description of the spatial distribution of $\mathrm{CN}$ is probably required.

631 Using SPC QPE, the numbers of false alarms is very high. Indeed, they represent 632 between $90 \%$ and $100 \%$ of the warnings delivered at the beginning of the storm, then 633 they drop to $85 \%$ during the night. Although this ratio may seem important, the number 634 of COR is high (close to 99\%). That means despite a significant number of false alarms, 635 the RIWS is able to rate the safe roads at the watershed scale. In order to have an 636 overview on the whole road network, the warnings issued by the RIWS during all the 637 storm are represented on Figure 7. 149 of the 468 existing intersections are identified as 638 inundated sections at some point in the night (but not simultaneously). Among them, 13 639 correspond to effective submersions which 12 are characterized by high and significant 640 risk. All the warnings are concentrated in areas particularly risky. That means the RIWS 641 can capture the spatial repartition of floodings when accurate QPE are used.

642 Finally, the results obtained with MF QPE are less satisfactory than those obtained with 643 SPC QPE. With a maximum of $50 \%$ for POD, the RIWS detections appear not to be 644 satisfactory. The use of $\mathrm{CN}=40$ does not permit the RIWS to deliver warnings during 645 the night. The simulated discharges are probably too low. As rainfall estimates from MF 646 are lower than those produced by SPC, $\mathrm{CN}$ has to be higher to simulate discharges 647 susceptible to exceed the different thresholds. Setting the CN equal to 50, it is not yet 648 sufficient and the results obtained with kriged data are still better. Only the optimised 649 CNcal -higher than 50- gives acceptable skill scores (Fig. 6). The detected inundated 650 roads are those located around Sommières where the estimates were the most intensive. 651 The other inundations located a little South of Sommières and detected by the RIWS 652 using SPC data are not identified here. As seen in Figure 2, SPC estimates tend to 
653 extend the intense rainfall core to the North part of the region - as it can be confirmed 654 by kriged data, and this is not reproduced by MF data.

655 Using the three best cases (calibrated CN for MF, SPC and kriging data), the warning 656 thresholds have been reduced in order to detect all the floodings ( $P O D=100 \%$ ). It has to

657 be noticed that a reduction of $90 \%$ of the threshold was necessary to detect every 658 flooded roads, because one of the floodings was located in an area little affected by the 659 intense precipitation (see Section 4.3.3). The evolution of POD and FAR skill scores are 660 represented on Figure 8. One more time, it seems that detections using radar-based QPE 661 are more efficient that those using kriging data. For a same value of POD, FAR score is always slightly lower for both MF and SPC data. Moreover, only kriging-based QPE

663 has issued $100 \%$ of false alarms, while the other QPE always issue effective warnings. 664 It could confirm that radar-based QPE better represent the spatio-temporal structure of 665 precipitation.

\section{4.3.2 On the improvement brought by $Q P F$}

667 The use of QPF seems to be interesting in road submersion forecasting. All the results offer a significant anticipation (between 15 to 45 minutes), at least during the crucial steps of the event when POD highly increases, between 22:00 and 00:00. This anticipation is extended to the previous time steps depending on the accuracy of the QPE-based detection. Indeed, the contribution of forecasts looks being correlated with the quality of the detection noticed using QPE. A better anticipation resulting from the RIWS occurs when using SPC QPF, and among them, those obtained with the calibrated CN (see Figure 6). When small values of CN (40) are used, SPC QPF data provide less significant information. MF QPF appears to be useful only between 22:30 and 23:30, when they allow preventing from inundations with a lead-time of 30 minutes. During this short period, COR and FAR are better. Despite the propagation of

678 the convective system to the east, the use of MF QPF appears to improve the skill 679 scores, especially when the most intense precipitation occurred.

680 Regarding the best case (calibrated CN for SPC data), radar-based QPF can help to 681 detect in advance the floodings during the entire storm. Skill scores obtained with 682 QPF15 are very similar to those obtained with QPE but with an anticipation of 15 683 minutes, meaning the quality of the rainfall forecast is quite good. The use of QPF30, 684 QPF45 and QPF60 allow to detect the submersions with an advance comprised between 
68515 and 45 minutes, reflecting the quality of forecasts deteriorates with lead time.

686 Regarding the response time of the concerned small watersheds (around 30 minutes),

687 this anticipation of 45 minutes appears to be very important. In this case, the 688 anticipation offered by simulations based on QPE is too limited to prevent from the 689 submersion. Note the inundations detected during this anticipation time follow strictly 690 the order of the inundations detected with the only QPE and that really occurred: 691 starting from the submersions located on the west part on the study area until the 692 inundations that occurred downstream the Vidourle watershed.

693

694 4.3.3 On the RIWS transfer and the use of the susceptibility analysis

695 Overall, the results provided for this particular storm are quite similar to those obtained 696 for the three storms studied during the calibration step (see Versini et al., 2010a) that are 697 summarized in Table 4 and Figure 9. On the calibration area, the good results obtained 698 in terms of flooding detection were due to the use of the susceptibility analysis. It 699 allowed to focus in priority the RIWS on the most vulnerable road sections without 700 having detailed rainfall estimate. The POD score was generally higher than $85 \%$ with a 701 COR score very close to $100 \%$. Nevertheless, the number of false alarms was yet 702 significant with more than $60 \%$ of the warnings issued. Without the susceptibility analysis, the accuracy of the RIWS dropped significantly with POD around to 70\% and higher FAR score, reaching $100 \%$ during the event. When comparing the results obtained on calibration and current areas in ROC space, it appears that the use of susceptibility analysis in calibration area allowed to improve the number of detections while decreasing the number of false alarms. It is not the case on the Vistre/Vidourle area, where the use of the susceptibility analysis seems to not be so significant and only leads to decrease the total number of issued warnings (both correct warning and false alarms scores are lower). Although they are not represented here, the skill scores have

711 almost the same distribution if the susceptibility analysis is used or not to characterize

712 the road intersections (see Table 4). The good scores provided by the best case 713 (calibrated CN for SPC data) may result from the use of spatially distributed QPE. Here, 714 the RIWS is focus in priority on the locations where the precipitation was the most 715 intense. Two points can be noted to explain the limit of the susceptibility analysis 716 transfer. 
717 When the susceptibility analysis is used, intersections characterized by a high 718 susceptibility can be hit by a warning without the two years return period being exceeded. Most of the intersections characterized by the highest level of susceptibility are located downstream of the Vistre and Vidourle watersheds, where subcatchments are, in general, bigger and flatter. Fortunately, this part of the territory was affected by intense rainfall, and many warnings were also reported, reaching $100 \%$ of false alarms at the beginning of the event. If the storm had been further north, the results would have probably been different. Second, the flooded road classified in the safe category is not identified as potentially inundated section when the susceptibility analysis is used. It is located downstream a very small catchment of $0.95 \mathrm{~km}^{2}$ in the upper North part of the Vidourle watershed. Here, rainfall was heavy but not sufficient to exceed the fifty years return period discharge threshold required to deliver a warning. Indeed, the simulated discharge is characterized by a two years return period. We can hypothesize that local structural problem (under-dimensioning, jam, falling tree...) could have been responsible for the flooding.

732

733

734

735

736

737

\section{5- Conclusion}

The Road Inundation Warning System developed for flash flood prone areas, and recently calibrated on the North part of the Gard region, has been applied on the South part of the Gard. Working in a framework simulating operational conditions, the RIWS has been tested to predict the inundated roads during the 29-30 September 2007 event. These results obtained for this specific storm event are very similar to those obtained in the calibration area (Versini et al., 2010b). They are promising and encourage the use of radar based spatial rainfall data. This convective storm with important spatial variability is particularly interesting to legitimate the use of the weather radar. The prototype is able to rate the inundation risk with an acceptable level of accuracy: despite many false alerts, it has a relatively high probability of detection (proportion of actually flooded points affected by a significant risk level around $80 \%$ in the best case), and a good detection of non-flooded roads (correct negative higher than 98\%). From these results, some conclusions can be made on the transfer of the RIWS on a region it has not been calibrated, and on the use of radar-based QPE and QPF delivered by both services in charge of hydro-meteorological risk management. 
751 The use of weather radar QPE, a priori more representative of the spatio-temporal variability of rainfall than kriged rainfall fields based on rain gauge measurements, seem to provide better results when they are not too biased. By using a simple rainfallrunoff model, simulated discharges at the stream gauges have been improved by taking into account the spatio-temporal distribution of rainfall as depicted from radar data. Conversely, simulations using rough spatio-temporal resolution of kriged data are less satisfactory. This tends to confirm the spatial variability represents a major source of temporal variability in hydrological simulation (Obled et al., 1994; Sempere-Torres et al., 1999). Second, the use of radar-based QPE has improved the detection of road inundations. Skill scores are almost always better than those obtained with kriged data. As expected, radar-based QPE allow to better represent the structure of rainfall on small watersheds. When only kriged data are used, most of the non-detected inundations are located downstream small watersheds with an area smaller than $10 \mathrm{~km}^{2}$. It has been noted that both services (SPC and MF) do not provide radar-based QPE with the same accuracy for this particular case of the 29-30 September 2007 storm. While SPC QPE show a trend to overestimate rainfall on the Vidourle watershed, both services seem to describe correctly rainfall on the Vistre watershed. This conclusion is specific of this particular case study and should be different for another storm.

Adding radar-based QPF in real time can also improve the detection of inundations, especially for the cases where radar-based QPE already produced good results. In the best cases, the use of QPF can anticipate the inundations with up to 45 minutes ahead. This can represent valuable information from a practical point of view. Knowing that a severe storm will occur (a warning has been issued few hours before the beginning of intense rainfall) the road management and rescue services are prepared to intervene. If they receive the information where the roads could be flooded 30 or 45 minutes before it happen, they will have the opportunity to communicate and optimize the deployment of its teams. For now, the RIWS prototype should therefore not be considered as a decision support system but rather as a useful source of information - possibly completed by field observations - that can help the emergency services during a flood event to improve their decision.

The RIWS has shown a significant sensibility to precipitation input and rainfall-runoff model calibration. Using accurate radar-based QPE, the RIWS could be used to assess the results of the selected hydrological model and/or the definition of discharge 
784 thresholds on ungauged basins. The results have demonstrated that the detection of 785 flooding is very sensitive to the $\mathrm{CN}$ values (skill scores are usually better when $\mathrm{CN}$ is 786 higher). The value of $\mathrm{CN}$ implemented on the ungauged area can also be discussed. 787 Moreover, despite the difference between both SPC and MF estimates, almost all the 788 inundated roads located on small streams of the Vistre watershed are missed, because 789 the simulated discharges did not exceed any warning thresholds. One explanation could 790 be that the average $\mathrm{CN}$ calibrated to simulate discharge on the main stream of the Vistre 791 basin is not sufficient to reproduce correctly the discharges (underestimated) on small internal watersheds. The method proposed by Versini et al., 2010a) and calibrated on the North rural part of the Gard region to estimate a priori a range of two CN values may be unadapted here. $\mathrm{CN}$ values could probably be modified to take into account better the specificity of the land cover (very urbanized with the presence of the city of

796 Nîmes) and the initial soil moisture. Another alternative is that theoretical return period 797 thresholds, adjusted from a large-scale study, are here overestimated. Despite the 798 intense rainfall and an acceptable simulation at Le Cailar, too few two years return 799 period threshold are exceeded. As illustrated in the study, one way to estimate new 800 discharge thresholds could be to adjust them in order to enable the RIWS to issue 801 warnings for the submerged roads that occurred in this watershed. In general, the 802 adjustment of new $\mathrm{CN}$ and threshold values will need additional events causing 803 floodings in this area. Particular attention should be made on the real cause of the 804 submersions in order to not to force the detection of a flooded road due to local 805 structural problem.

806 Finally, the susceptibility analysis that has been previously developed on the North part 807 of the Gard region has appeared to not be very satisfactory, for this particular event, on 808 the South part, flatter and more urbanized. Despite inundated roads are classified in the 809 highest susceptibility categories, numerous false alarms have been issued at the 810 beginning of the event by the RIWS. This is due to the location of intense precipitation 811 where intersections characterized by the highest level of susceptibility are concentrated.

812 In the downstream part, too many intersections are comprised in this category, meaning 813 discharges characterized by return periods shorter or equal to two years are sufficient to 814 flood roads. Of course it is not true, but as a consequence too many road sections are 815 identified as flooded. On the other hand, the presence of a submerged road in the safe 816 category illustrates the method could not be adapted to this part of the Gard region. 
817 Additional future events and submerged roads should be also necessary to grow the size

818 of the different susceptibility categories and be more conclusive. This method could be 819 modified in function of the specific configuration of the environment, but also be 820 completed by post-field investigations (Gaume and Borga, 2008). The characterization

821 of susceptibly, as discharge thresholds definition, could be improved with time and

822 accumulation of damage data.

823 Nowadays, the RIWS seems to have potentials for capturing timing, magnitude, and 824 spatial repartition of the flooding risk. Using accurate QPE and QPF, it gives indications 825 about the areas where the roads are flooded, but inside theses areas, a lot of false alarms 826 are issued. That is why the susceptibility analysis represents a key part of the RIWS and 827 should be improved. A good susceptibility analysis will allow to focus on the most 828 vulnerable road sections and capture effectively the magnitude of the risk. Since no 829 information is available on the time of inundation, we cannot conclude on the ability to 830 capture the timing for now. The complementarity between the timing, the spatial 831 repartition and the magnitude of the warning will make the RIWS reliable to define safe 832 itineraries and/or prepare interventions from an operational point of view.

837 The study described in this paper has been carried out with the help of Meteo France 838 and the Direction Départementale de l'Equipement du Gard which provided radar QPE 839 and QPF data. Special thanks are due to the INPG of Grenoble and the OHM-CV 840 (Cevennes-Vivarais Hydro-Meteorological Observatory) and especially Guy Delrieu, 841 Laurent Bonnifait and Brice Boudevillain for providing historical meteorological data 842 on the Gard region. The author thanks especially Eric Gaume from the Laboratoire 843 Central des Ponts et Chaussées for sharing Prediflood project data 844 (http://heberge.lcpc.fr/prediflood/). 


\section{Reference}

Antoine, J.-M., Desailly, B. and Gazelle, F., 2001. Les crues meurtrières, du Rousillon aux Cévennes. Annales de Géographie, 110(622): 597-623.

Ayral, P.-A., 2005. Contribution à la spatialisation du modèle opérationnel de prévision des crues éclair ALTHAÏR, Université de Provence Aix-Marseille I, 310 pp.

Berenguer, M., Corral, C., Sánchez-Diezma, R. and Sempere-Torres, D., 2005. Hydrological Validation of a Radar-Based Nowcasting Technique. Journal of Hydrometeorology, 6(4): 532-549.

Borga, M., 2008. Realtime guidance for flash flood risk management.

Borga, M., Degli Esposti, S., Norbiato, D., , 2006. Influence of errors in radar rainfall estimates on hydrological modelling prediction uncertainty. Water resources Research, 42(8).

Boudevillain, B., Andrieu, H. and Chaumerliac, N., 2006. Evaluation of RadVil, a Radar-Based Very Short-Term Rainfall Forecasting Model. Journal of Hydrometeorology, 7(1): 178-189.

Bourque, L., Siegel, J., Kano, M. and Wood, M., 2007. Morbidity and mortality associated with disasters. In: Springer (Editor), Handbook of disasters research, pp. 97-112.

Bressand, F., 2002. Le projet ALHTAÏR du service d'annonce des crues du Gard. La Houille Blanche, 2: 64-68.

Cemagref, 1980. Synthèse nationale sur les crues des petits bassins versants: Méthode SOCOSE et CRUPEDIX.

Chancibault, K., Anquetin, S., Ducrocq, V. and Saulnier, G.-M., 2007. Hydrological evaluation of high-resolution precipitation forecasts of the Gard flash-flood event (8-9 September 2002). Quarterly Journal of the Royal Meteorological Society, 132: 1091-1117.

CNRS/INPG, 1997. Atlas expérimental des risques de pluies intenses, région CévennesVivarais, Grenoble, France.

Cole, S.J. and Moore, R.J., 2008. Hydrological modelling using raingauge and radarbased estimators of areal rainfall. Journal of Hydrology, 358(3): 159-181.

Collier, C.G., 2007. Flash flood forecasting: GAT are the limits of predictability. Quarterly Journal of the Royal Meteorological Society, 133: 3-23.

Corral, C., Sempere-Torres, D., Revilla, M. and Berenguer, M., 2000. A semidistributed hydrological model using rainfall estimates by radar. Application to Mediterranean basins. Physics and Chemistry of the Earth, Part B: Hydrology, Oceans and Atmosphere, 25(10-12): 1133-1136.

Creutin, J.-D. and Borga, M., 2003. Radar hydrology modifies the monitoring of flash flood hazard. Hydrological processes, 17(7): 1453-1456.

Creutin, J.-D., Borga, M., Lutoff, C., Scolobig, A., Ruin, I., Créton-Cazanave, L., , 2009. Catchment dynamics and social response during flash floods: the potential of radar rainfall monitoring for warning procedures. Meteorological Applications, 16: 115-125.

Delrieu, G., 2004. L'Observatoire Hydro-météorologique Méditerranéen CévennesVivarais (The Cévennes-Vivarais Mediterranean Hydro-meteorological Observatory). La Houille Blanche, 6: 83-88.

Delrieu, G., Ducrocq, V., Gaume, E., Nicol, J., Payrastre, O., Yates, E., Andrieu, H., Ayral, P.-A., Bouvier, C., Creutin, J.-D., Livet, M., Anquetin, S., Lang, M., Neppel, L., Obled, C., Parent-du-Chatelet, J., Saulnier, G.-M., Walpersdorf, A. and Wobrock, W., 2005. The catastrophic flash-flood event of 8-9 September 
2002 in the Gard region, France: a first case study for the Cévennes-Vivarais Mediterranean Hydro-meteorological Observatory. Journal of Hydrometeorology, 6: 34-52.

Dolciné, L., Andrieu, H., Sempere-Torres, D. and Creutin, D., 2001. Flash Flood Forecasting using a Coupled Precipitation Model in Mountainous Mediterranean Basin. Journal of Hydrologic Engineering 6(1): 1-10.

Gaume, E., Bain, V., Bernardara, P., Newinger, O., Barbuc, M., Bateman, A., Blaskovicova, L., Bloschl, G., Borga, M., Dumitrescu, A., Daliakopoulos, I., Garcia, J., Irimescu, A., Kohnova, S., Koutroulis, A., Marchi, L., Matreata, S., Medina, V., Preciso, E., Sempere-Torres, D., Stancalie, G., Szolgay, J., Tsanis, I., Velasco, D. and Viglione, A., 2009. A compilation of data on European flash floods. Journal of Hydrology, 367(1-2): 70-78.

Gaume, E. and Borga, M., 2008. Post-flood field investigations in upland catchments after major flash floods: proposal of a methodology and illustrations. Journal of Flood Risk Management, 1(4): 175-189.

Gaume, E., Livet, M., Desbordes, M. and Villeneuve, J.-P., 2004. Hydrologic analysis of the Aude, France, flash flood 12 and 13 November 1999. Journal of Hydrology, 286: 135-154.

Journel, A.G. and Huijbregts, C., 1978. Mining Goestatistics, Academic Press, London.

Juvanon du Vachat, R., Chèze, J.-L. and Sénési, S., 1995a. Nowcasting storms and precipitation over Ile-de-France: the Aspic project. In: A.M. Soc. (Editor), 11-th Conf. on Interactive Information Processing System for Meteorlogy, Oceanography and Hydrology, Dallas, Texas.

Juvanon du Vachat, R., Thomas, P., Bocrie, E., Monceau, G., Cosentino, P., Sénési, S., Tzanos, D. and Boichard, J.-L., 1995b. The precipitation nowcast scheme in the Aspic project, Second European Conf. on Applications of Meteorology, Toulouse, France, pp. 29-32.

Le Lay, M. and Saulnier, G.-M., 2007. Exploring the signature of climate and landscape spatial variabilities in flash flood events: Case of the 8-9 September 2002 Cévennes-Vivarais catastrophic event. Geophysical Research Letters, 34(13): 13401.

Lebel, T., Bastin, G., Obled, C. and Creutin, J.D., 1987. On the accuracy of areal rainfall estimation: a case study. Water Resources Research, 23(11): 2123-2134.

Lignon, S., 2004. Mise en place du plan d'intervention aux crises hydrologiaues $(\mathrm{PICH})$ à la DDE du Gard, Ecole des Mines d'Alès, Université de Montpelier.

Moulin, L., E., G. and C., O., 2009. Uncertainties on mean areal precipitation: assessment and impact on streamflow simulations. Hydrology and Earth System Sciences, 13: 99-114.

Nash, J.E., 1969. A course of lecture on parametric or analytical hydrology. In: L. $\mathrm{n}^{\circ} 12$ (Editor), University of Toronto.

Obled, C., Wendling, J. and Beven, K., 1994. The sensitivity of hydrological models to spatial rainfall patterns: an evaluation using observed data. Journal of Hydrology, 159(1-4): 305-333.

Ruin, I., Creutin, J.-D., Anquetin, A. and Lutoff, C., 2008. Human exposure to flash floods - Relation between parameters and human vulnerability during a storm of September 2002 in Southern France. Journal of Hydrology, 1361(1-2): 199-213.

Sempere-Torres, D., Corral, C., Raso, J. and Malgrat, P., 1999. Use of weather radar for combined sewer overflows monitoring and control. Journal of Environmental Engineering, ASCE, 125: 372-380. 
Staes, C., Orengo, J.C., Malilay, J., Rullan, J. and No ji, E., 1994. Deaths due to flash floods in Puerto Rico, january 1992 : Implication for prevention. International Journal of Epidemiology, 23(5): 968-975.

Tabary, P., 2007. The new French radar rainfall product. Part I: methodology. Weather Forecasting, 22(3): 393-408.

Tabary, P., Desplats, J., Do Khac, K., Eideliman, F., Gueguen, C. and Heinrich, J.-C., 2007. The new French radar rainfall product. Part II : Validation. Weather Forecasting, 22(3): 409-427.

Van Horne, M.P., Vivoni, E.R., Entekhabi, D., Hoffman, R.H. and Grassotti, C., 2006. Evaluating the effects of image filtering in short-term radar rainfall forecasting for hydrological applications. Meteorological Applications, 13(3): 289-303.

Versini, P.-A., Gaume, E. and Andrieu, H., 2010a. Application of a distributed hydrological model to the design of a road inundation warning system for flash flood prone areas. Natural Hazards and Earth System Sciences, 10: 805-817.

Versini, P.-A., Gaume, E. and Andrieu, H., 2010b. Assessment of the susceptibility of roads to flooding based on geographical information - test in a flash flood prone area (the Gard region, France). Natural Hazards and Earth System Sciences, 10: 793-803.

Vivoni, E.R., Entekhabi, D., Bras, R.L., Ivanov, V.Y., Van Horne, M.P., Grassotti, C. and Hoffman, R.N., 2006. Extending the predictability of hydrometeorological flood events using radar rainfall nowcasting. Journal of Hydrometeorology, 7(4): 660-677.

Younis, J., Anquetin, S. and Thielen, J., 2008. The benefit of high-resolution operational weather forecasts for flash-flood warning. Hydrology and Earth System Sciences, 5: 345-377. 
$975 \quad$ Figure captions

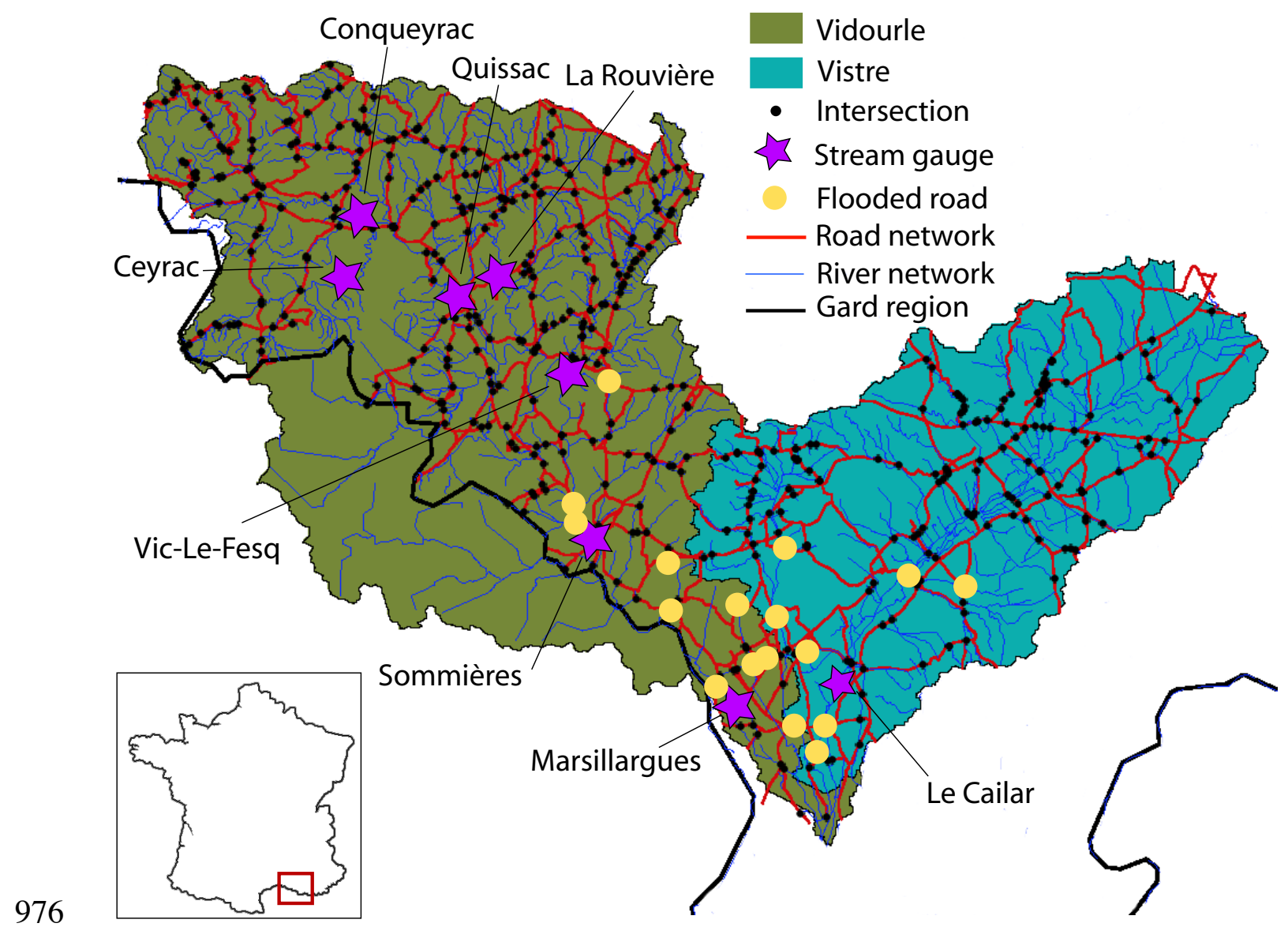

977 Figure 1. The Vidourle and Vistre watersheds 

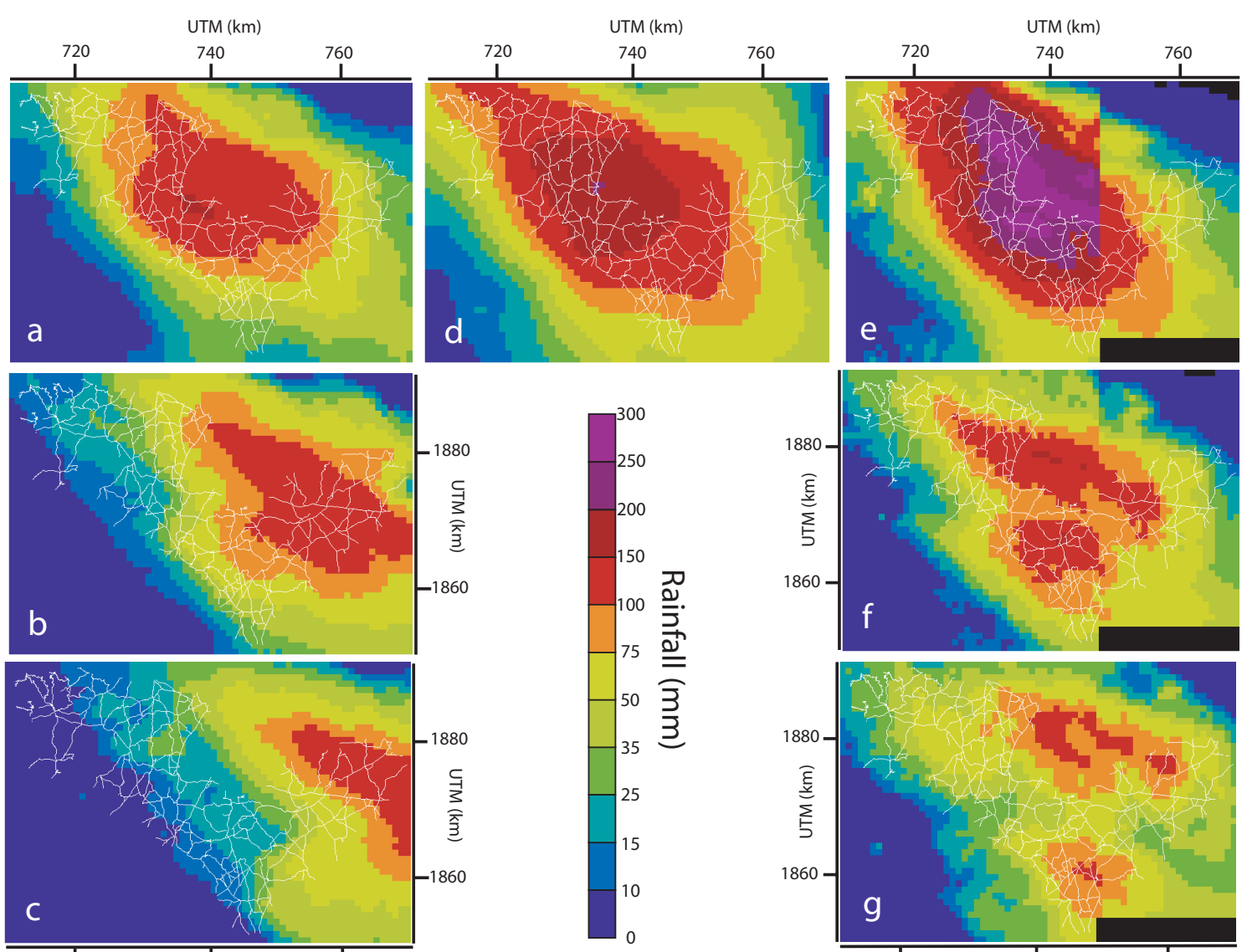

979
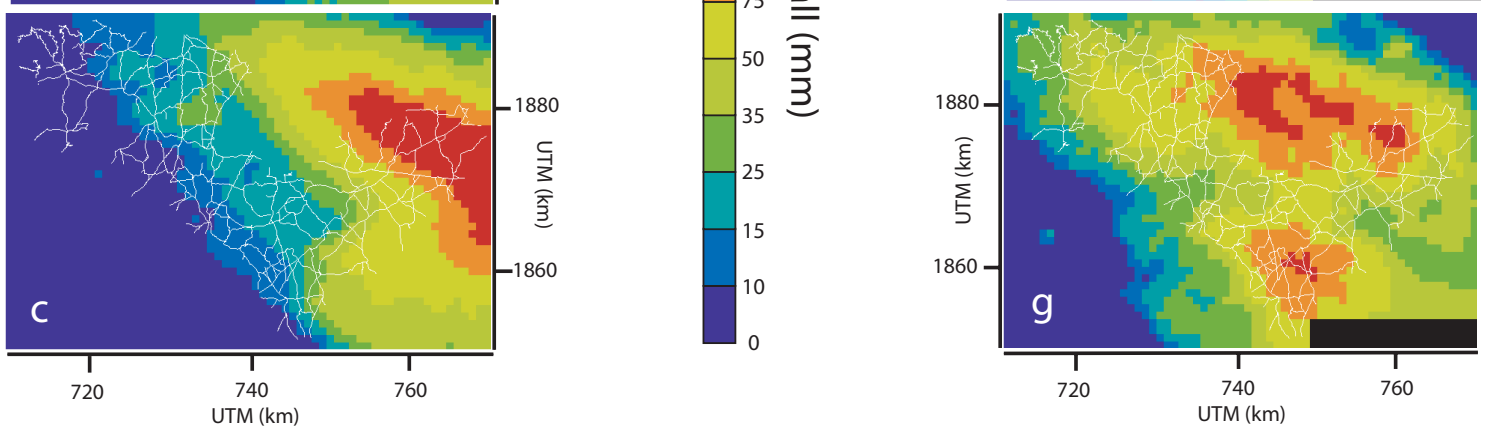

980

981

982

983

Figure 2. Rainfall accumulation: (a) MF QPE, (b) MF QPF30, (c) MF QPF60, (d) Kriging, (e) SPC QPE, (f) SPC QPF30, (g) SPC QPF60
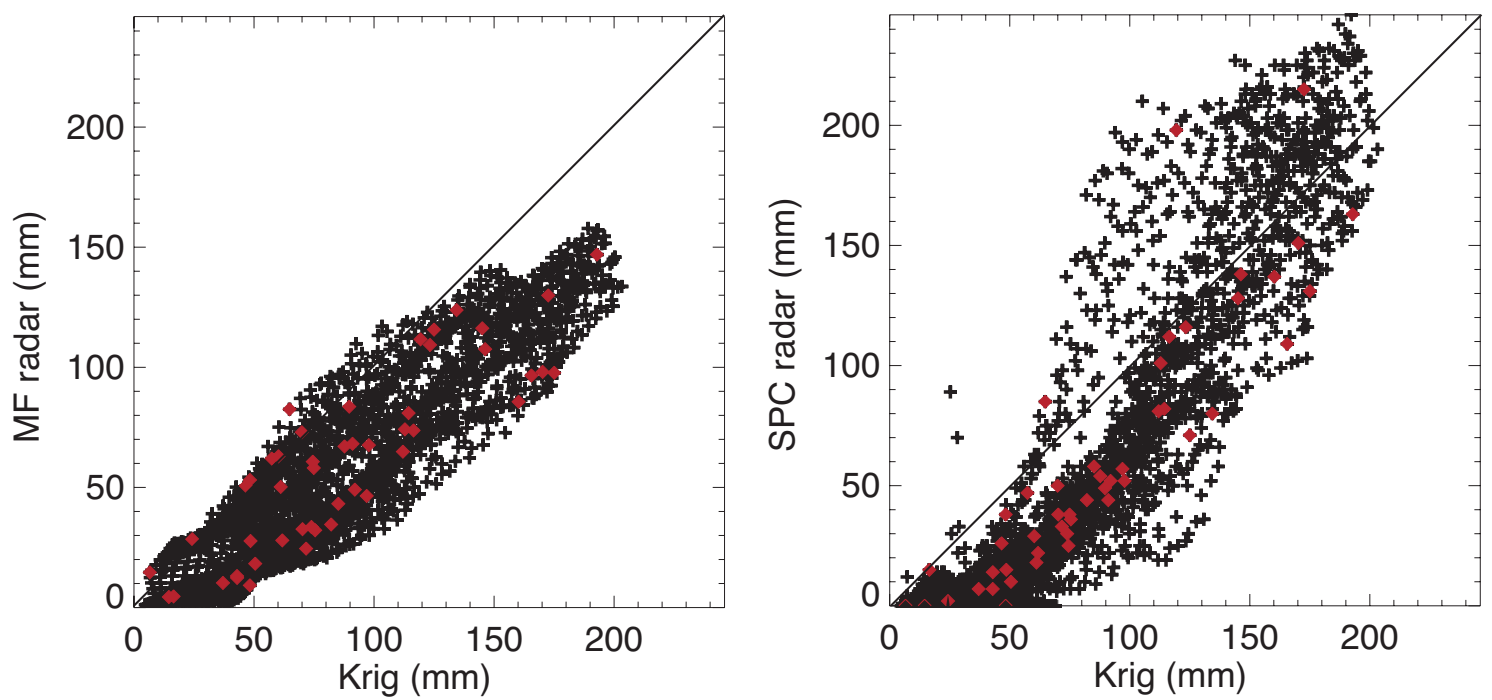

984

985

Figure 3. Scatter plots of precipitation accumulation at $1 \mathrm{~km}^{2}$, (a) comparison between 986 kriged data and SPC QPE, (b) comparison between kriged data and MF QPE. The red 987 

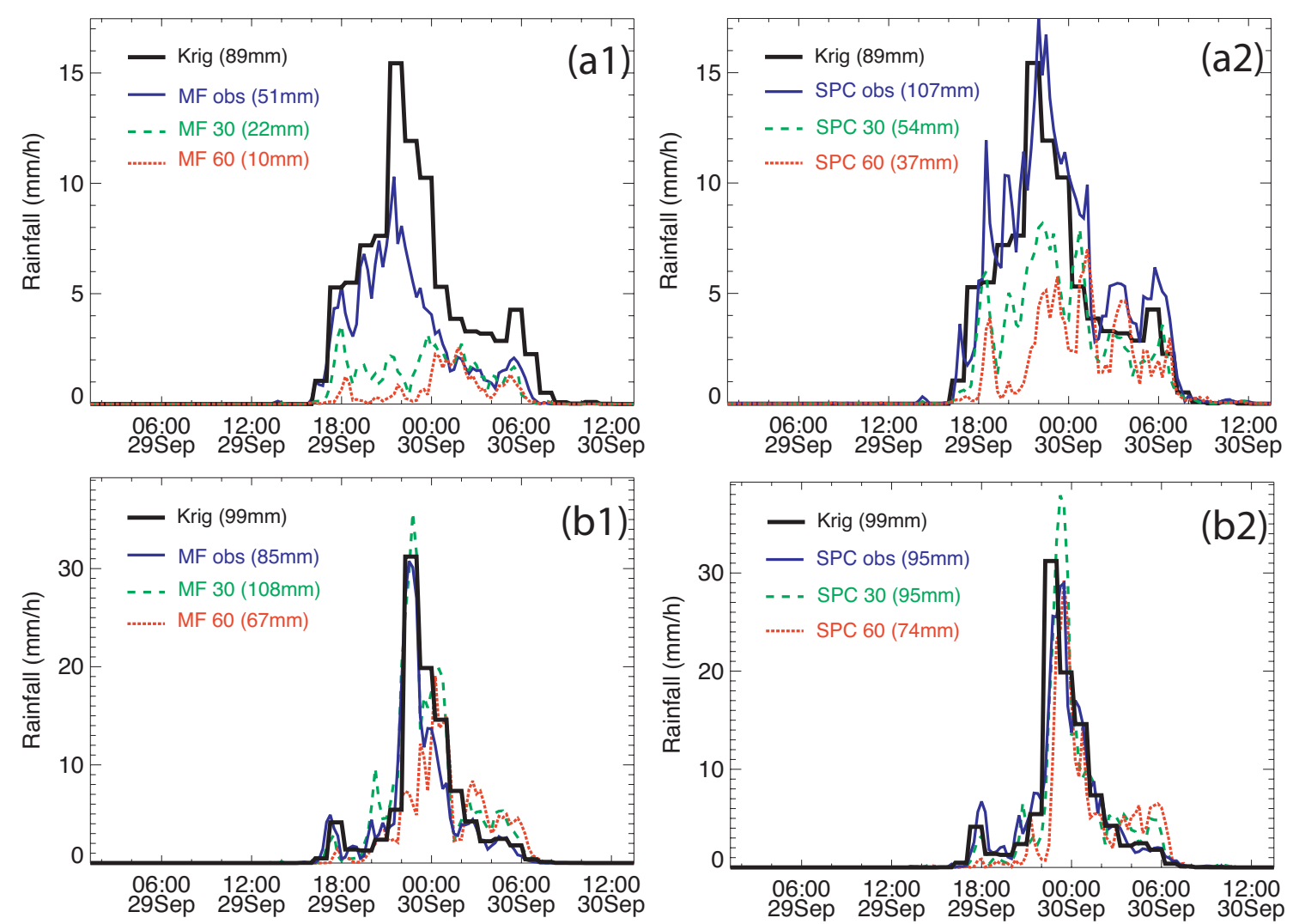

Figure 4. Rainfall hyetogram and total amount of precipitation on the Vidourle watershed (a) and on the Vistre watershed (b), for MF data (1) and SPC data (2). Precipitation estimate is represented by full line, 30 minutes forecast data by spaced dotted line, 60 minutes forecast data by small dotted line, and reference kriging data by large full line. 

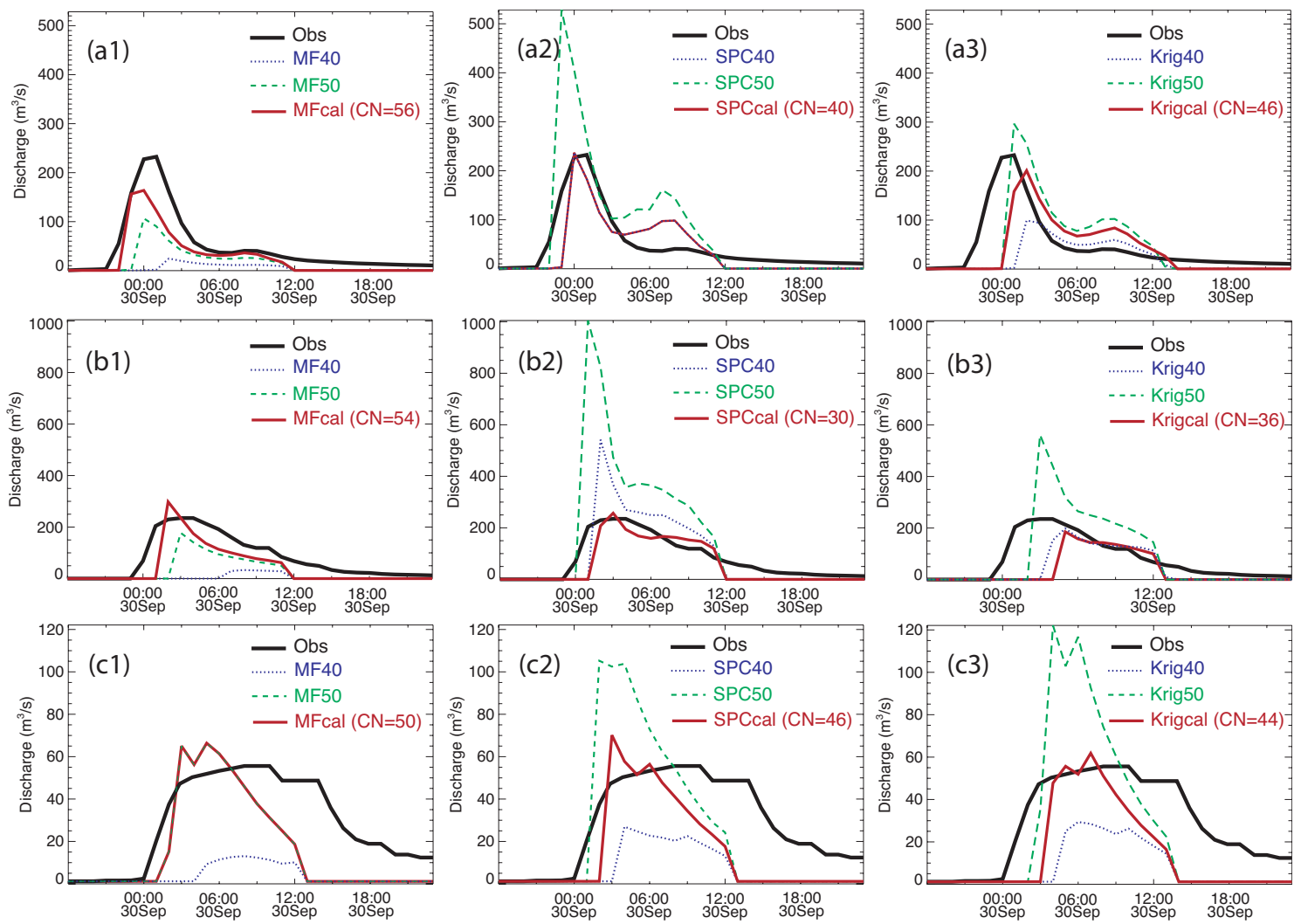

996

997

998

999

1000

1001

1002

1003

1004

1005

1006

1007

1008

1009

Figure 5. Discharge simulations on Sommières watershed (a), on Marsillargues watershed (b), and on Le Cailar watershed (c), using MF data (1), SPC data (2), and kriging data (3). Observations are represented by full large black line, simulations based on a priori $\mathrm{CN}$ (40 and 50) by small and spaced dotted line, and calibrated CN (the value of CNcal is written in parentheses) by full red line.
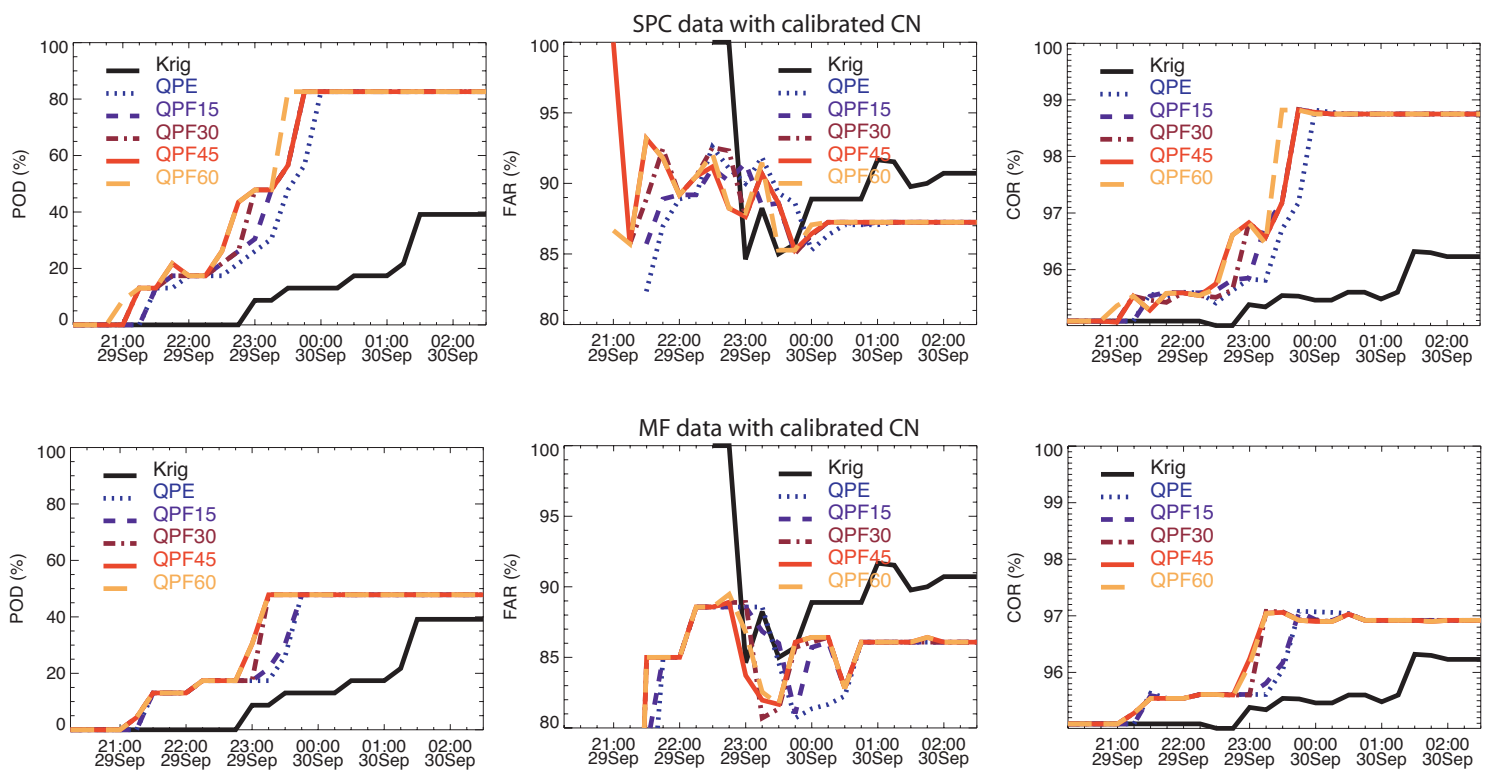

Figure 6. Skill scores for SPC data (top) and MF data (bottom) with calibrated CN. QPE represents the skill score calculated with the only estimations, $Q P F 15$ those with the 15 minutes forecast added, respectively $Q P F 30, Q P F 45, Q P F 60$ with the 30, 45, and 60 minutes forecasts added. Finally, Krig represents the skill score computed using kriged data 
1010

1011 1012 1013

1014

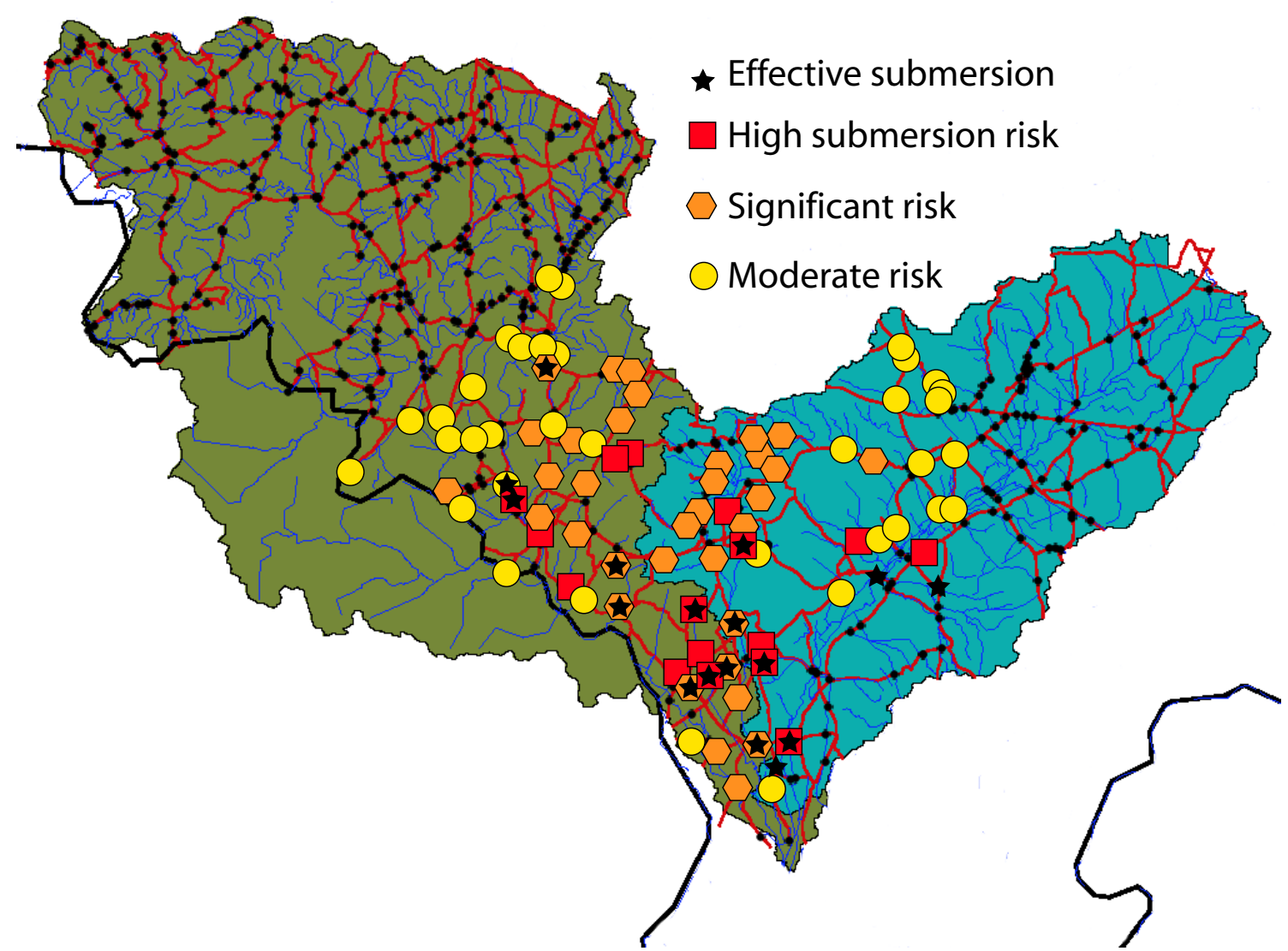

Figure 7. Warnings issued by the RIWS during all the event using SPC QPE, CNcal and the susceptibility analysis

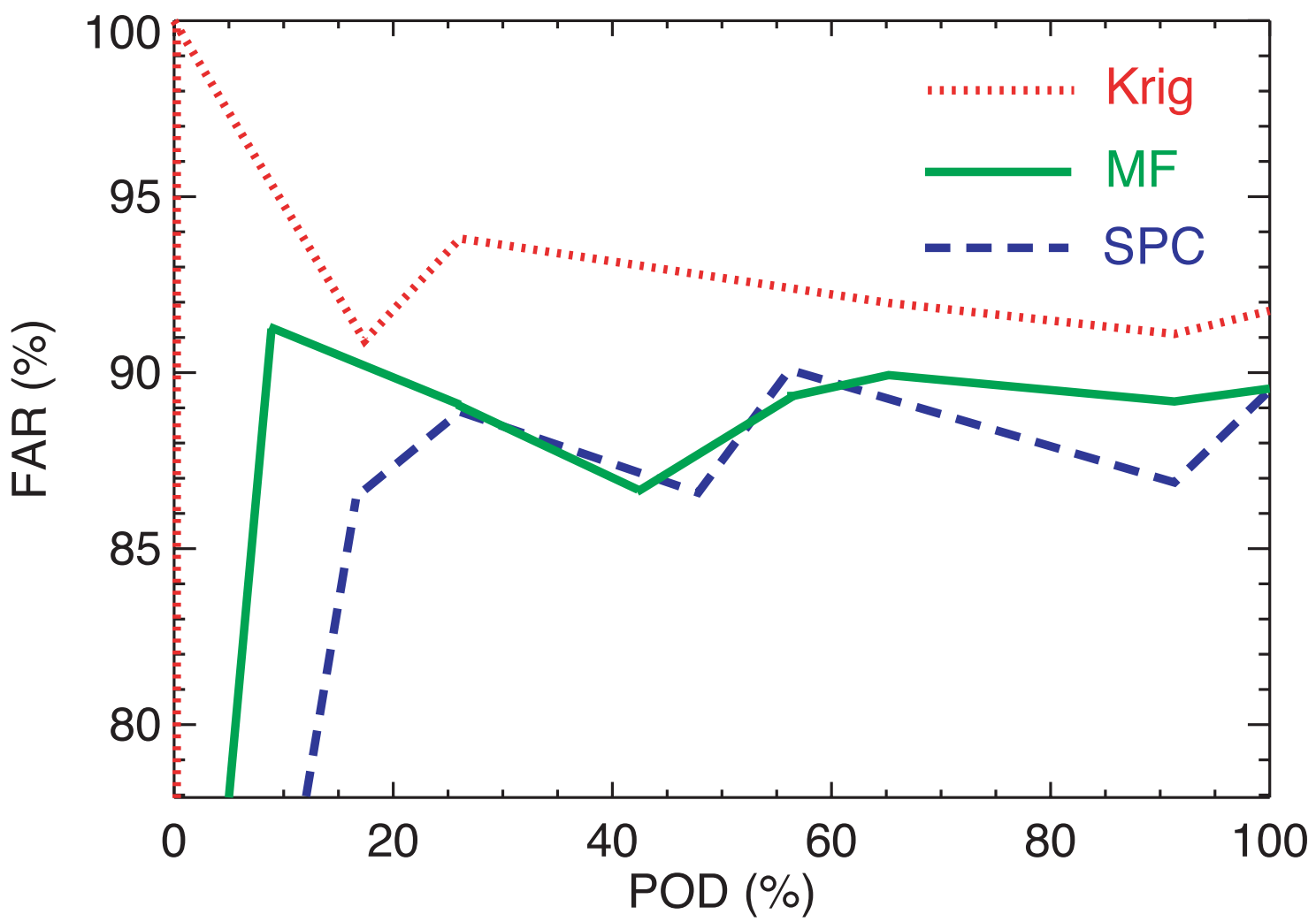

Figure 8. Evolution of FAR and POD skill scores reducing the warning threshold for kriging, MF and SPC QPE using the calibrated $\mathrm{CN}$. 


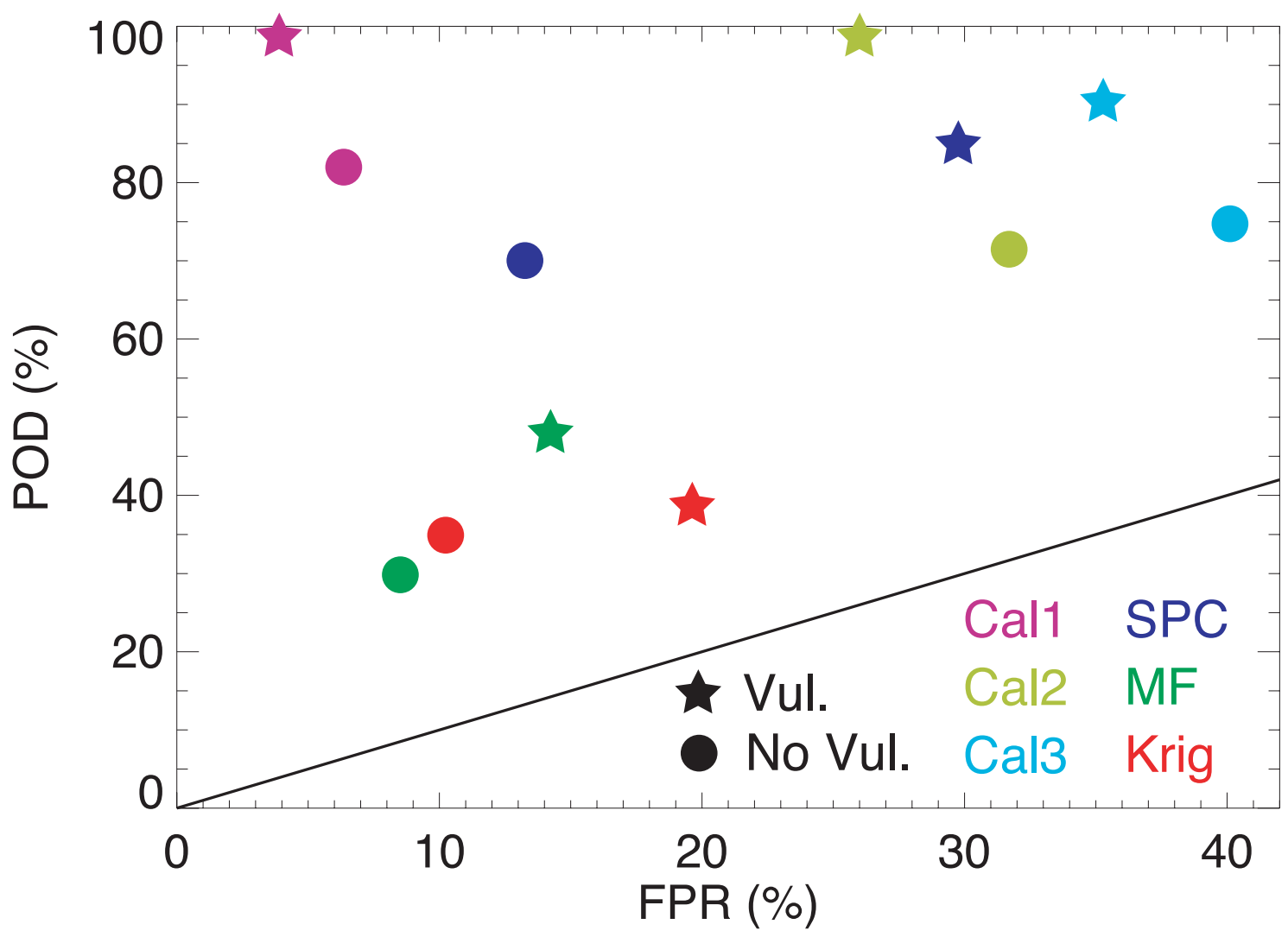

1018

1020

1021

1022

1023

1024

1025

1026

1027

1028

1029

1030

1031

1032

1033

Figure 9. Inundation forecasts represented in the ROC space. The results obtained for the 3 calibration events (Cal1, Cal2 and Cal3) are compared to those computed with SPC, MF, and Krig QPEs. POD and FPR values are calculated using the total number of correct warnings and false alarms issued during the event.

\section{Table captions}

\begin{tabular}{lcccc}
\hline & $\mathrm{Q}_{2} / 2<\mathrm{Q}_{\operatorname{sim}}<\mathrm{Q}_{2}$ & $\mathrm{Q}_{2}<\mathrm{Q}_{\text {sim }}<\mathrm{Q}_{10}$ & $\mathrm{Q}_{10}<\mathrm{Q}_{\operatorname{sim}}<\mathrm{Q}_{50}$ & $\mathrm{Q}_{\text {sim }}>\mathrm{Q}_{50}$ \\
\hline Susceptibility High & $\mathrm{SR}$ & $\mathrm{HSR}$ & $\mathrm{HSR}$ & $\mathrm{HSR}$ \\
Susceptibility Medium & $\mathrm{MR}$ & $\mathrm{SR}$ & $\mathrm{SR}$ & HSR \\
Susceptibility Low & No risk & MR & MR & SR \\
Safe & No risk & No risk & No risk & MR \\
\hline No susceptibility analysis & No risk & MR & SR & HSR \\
\hline
\end{tabular}

Table 1. Risk levels based on exceeded discharge thresholds - with susceptibility category or without

\begin{tabular}{|l|c|c|c|}
\hline Category of susceptibility & Calibration area & Study area & Submerged intersections \\
\hline High & $8 \%$ & $12 \%$ & $35 \%$ \\
\hline Medium & $22 \%$ & $20 \%$ & $30 \%$ \\
\hline Low & $54 \%$ & $50 \%$ & $30 \%$ \\
\hline Safe & $16 \%$ & $18 \%$ & $5 \%$ \\
\hline
\end{tabular}

Table 2. Repartition of the road sections between the four susceptibility categories using the road susceptibility rating method applied on the previous calibration area, on the Vistre and Vidourle area and on the 29-30 September 2007 storm flooded road 
1034

\begin{tabular}{lccccccccc}
\hline & SPC40 & SPC50 & SPCcal & MF40 & MF50 & MFcal & Krig40 & Krig50 & Krigcal \\
\hline Sommières & 0.81 & -0.65 & 0.81 & -0.18 & 0.44 & 0.73 & 0.00 & -0.13 & 0.28 \\
Marsillargues & 0.19 & -4.05 & 0.70 & -0.32 & 0.40 & 0.67 & 0.18 & -0.19 & 0.35 \\
Le Cailar & 0.03 & -0.06 & 0.39 & -0.26 & 0.43 & 0.43 & 0.10 & -0.24 & 0.37 \\
\hline
\end{tabular}

1035

1036 Table 3. Nash efficiency for discharge estimation using $\mathrm{CN}=40, \mathrm{CN}=50$ and $\mathrm{CNcal}$ for

1037 the following watersheds: Sommières (a), Marsillargues (b), and Le Cailar (c)

1038

\begin{tabular}{|l|ccc|ccc|ccc|c|}
\hline & \multicolumn{3}{|c|}{ SPC } & \multicolumn{3}{c|}{ MF } & \multicolumn{3}{c|}{ Krig } & Cal \\
\hline & 40 & 50 & Cal. & 40 & 50 & Cal. & 40 & 50 & Cal. & \\
\hline POD & $60.2 / 56.5$ & $82.6 / 78.3$ & $82.6 / 69.6$ & $0 / 0$ & $34.8 / 17.4$ & $47.8 / 30.4$ & $14.0 / 0$ & $58.3 / 50.1$ & $39.1 / 34.8$ & $\mathbf{7 6 . 0 / 9 6 . 0}$ \\
COR & $97.8 / 97.6$ & $98.8 / 98.6$ & $98.8 / 98.2$ & $95.2 / 95.4$ & $96.5 / 95.7$ & $97.1 / 96.2$ & $95.5 / 0$ & $97.3 / 97.1$ & $96.3 / 96.3$ & $\mathbf{9 6 . 3 / 9 8 . 2}$ \\
FAR & $90.2 / 75.5$ & $87.3 / 84.8$ & $87.2 / 78.4$ & $0 / 0$ & $86.7 / 90.0$ & $86.1 / 85.4$ & $86 / 100$ & $87.3 / 89.5$ & $93.7 / 87.7$ & $\mathbf{6 3 . 0 / 7 3 . 0}$ \\
\hline
\end{tabular}

1039

1040 Table 4. Summary of the RIWS maximum skill scores for the different types of QPE 1041 (SPC, MF and kriged data) and different $\mathrm{CN}$ values. The left value is computed without 1042 considering the susceptibility analysis, the right one considering the susceptibility. The 1043 last column contains the average results obtained in the calibration area for 5 events. 